\title{
Bir Medya Aracı Olarak Sinemanın Din Eğitiminde Kullanımı: Baudrillard'ın Simülasyon Teorisi Bağlamında Bir Değerlendirme
}

The Possibility of Using Cinema as a Media Tool in Religious Education: An Evaluation in The Context of Baudrillard's Theory of Simulation

Süleyman GÜMÜŞ, Sorumlu Yazar, Dr.

E-mail: suleymangumus@yahoo.com

ORCID: 0000-0003-2202-5121

ISSN: 1303-880X

e-ISSN: 2667-7504 http://ded.dem.org.tr

Geliş/Received: 27.10.2017

Kabul/Accepted: 31.10 .2019

Makale Yayın: 25.12.2019

Makale Türü/Article Type:

Araştırma/Research
Atıf/Citation: Gümüş, S. (2019). Bir medya aracı olarak sinemanın din eğitiminde kullanımı: Baudrillard'ın simülasyon teorisi bağlamında bir değerlendirme. Değerler Ĕgitimi Dergisi, 17 (38), 7-40. DOI: 10.34234/ded.347162 
Öz: Bu makale, Jean Baudrillard'ın Simülasyon Kuramı üzerinden, din eğitiminde sinemanın kullanılabilirliğini analiz etme amacını taşımaktadır. Çalışma, üç bölümden oluşmaktadır: birinci bölümde simülasyon kuramı açıklanmış; ikinci bölümde, simülasyonun bireyi ve toplumu dönüştürmesi üzerinde durulmuş ve son bölümde de düşünür tarafından bir simülasyon modeli olarak kabul edilen sinemanın eğitsel imkân ve sınırll1ıkları değerlendirilmeye çal1şılmıştır. Bu amaçla, kendi tekil durumunun sınırlılığında din eğitiminin hedeflerine ulaştırmak için uygun görülen bir araç, kültür eleştirisi olan simülasyon teorisi merkeze alınarak tümel bir bakış açısında kritik edilmiştir. Din eğitiminin kazanımları ile öğretim araçları arasındaki ilişki, kendi dinamiği içinde bir gerçeklik haline gelebilmektedir. Söz konusu bu gerçeklik ise, dinin anlamının önüne geçme tehlikesini içermektedir. Özellikle din eğitiminin bilimsel statüsü, onun pratik bağlamını aşırı güçlendirerek antropolojik bir olgu olmasıyla sınırlandırabilir ki bu, dinin eğitim dolayımında dünyaya geri çekilmesi demektir. Simülasyon, gerçeğin yerine ikame edilmiş ve kökenden bağımsız olan yans1masını ifade etmektedir. Simülasyon evreni, göndergelerinden yoksun göstergelerin inşa ettiği sanal bir evrene göndermede bulunmaktadır. Baudrillard'a göre sinema filmi de bu evrende yer alan bir simülasyon modeli/simülakr olarak çalışmaktadır. Sonuçta anlamın aktarılamaması nedeniyle, din eğitiminin amaçladığı dini bilgiler ve ahlaki ilkelerin, bir yüzey olan sinema ekranı üzerinden izleyiciye aktarılması mümkün görünmemektedir. Filmlerin etkileyiciliği, bilinçdışının bağlarından ve sınırlardan kurtularak özgürleşmesi sonucu bir kendinden geçmesi haline benzemektedir.

Anahtar Kelimeler: Din eğitimi, Simülasyon, Simülakr, Anlam, Sinema.

$\&$

Abstract: This article aimed to analyze the possibility of using cinema as a tool in religious education based on Jean Baudrillard's simulation theory. This work consists of three parts: in the first part the simulation theory is explained; in the second part, the transformation of individual and society by simulation is dwelt on and in the last part, the educational possibilities and limits of cinema which accepted as a 'simulation model' by Baudrillard, is assessed. For this purpose, a suitable tool is in the limitation of its singular status, for reaching the goals of religious education was criticized by simulation theory which is cultural critique. The relationship between the learning outcomes of religious education and teaching tools can become a reality within its own dynamics. This reality involves the danger of preventing the meaning of religion. In particular, the scientific status of religious education can 
be limited to anthropological phenomenon by over-strengthening its practical context, which means that religion retreats to the culture through education. Simulation states the reflection of real world free from the origin which is replaced with the real one. The universe of simulation implies a virtual universe which consists of signs without reference. According to the Baudrillard, cinema, as being part of universe of simulation, works as a model of simulation/simulacr. Since the sense cannot be transferred, transferring religious knowledges and moral principles through cinema screen as a model is not possible. Impressiveness of movies is similar to ecstasy as a result of getting rid of liberation of the unconscious from its ties and limits.

Keywords: Religious education, Simulation, Simulacr, Sense, Cinema.

\section{Giriş}

Medyanın gündelik hayatta gittikçe artan rolü, olumlu ve olumsuz yönleri ya da imkân ve sınırlı1ıkları üzerine tartışmaları da beraberinde getirmektedir. Hemen her alanda kendine yer bulabilmiş olması, başka bir deyişle aracılık rolündeki başarısı, onun hakkında kesin bir karar vermeyi zorlaştırmaktadır. Dolasıyla kitle iletişimdeki niceliksel yönünden diğer alanlarda olduğu gibi, din eğitiminde de faydalanılması gerektiğini düşünenlerin yanında, modern dünyanın oldukça da modern bir ürünü olduğundan hareketle, doğası gereği her alanda kullanıma uygun olmadığı görüşüne sahip olanlar da bulunmaktadır. Örneğin, Televizyon Öldüren Eğlence, Çocukluğun Yokoluşu isimli kitapların yazarı Neil Postman, medya araçlarının bilgi aktarmaktan çok daha fazla bir işlevinin olduğunu, insanın varoluşunu derinden etkilediğini ileri sürmektedir (Postman, 1994; Postman, 1995).Genelde medya araçlarının, özelde ise sinema filminin, geleneksel toplumdan modern topluma geçişte, gündelik hayattaki en dikkat çeken göstergelerden bir tanesi olduğu söylenebilir. Buna bağlı olarak da kullanımıyla ilgili kuşku, ilettiği mesajın sadece istenilen mesajın olmadığı, ürünü olduğu dünya görüşünün etkilerinin zorunlu olarak mesajda da bulunduğu iddiası ile bağlantılıdır. Medyanın ilettiği mesajın, medyanın kendi mesajı olduğu önermesi, medya dolayımında aktarma ediminde, özellikle ilke ve değerler gibi normatif içeriklerin amacına uygun bir şekilde icra edilemeyeceğine işaret etmektedir (McLuhan, 2013). Özgül olarak medyaya yönelik bu tip eleştirilerin yanında, modern kültürün kendisinden hareketle medya eleştirisi yapanlar da bulunmaktadır. Ahlak ve sanat arasındaki geleneksel ilişkinin, sanatın estetiğe dönüşmesi ile birlikte bozulduğu, tüketim nesnesi ve aracı haline geldiği, bu nedenle de estetik dolayımında değerlerin temsilinin mümkün olmadığı ileri sürülmüştür 
(Benjamin, 2015, s.15 vd). Kültür eleştirisi üzerinden genelde medya, özelde sinema eleştirisi yapanlardan birisi de Jean Baudrillard'dır. Baudrillard'a göre modern kültürde göstergeler, göndergelerinden yoksun olduklarından, kendileri dışında başka bir şeye yani işaret ettikleri bir anlama sahip değillerdir. Bir tür nihilizm demek olan bu durum, modern hayatın duyusal/dünyevi bir kurgu olduğunu göstermektedir. Söz konusu bu kurgu, kültürün endüstriyel düzlemde üretilmekte olduğunu ve hümanizm, insan hakları, etik gibi modern dünyanın daha insani olduğunu kanıtlamak adına ileri sürülen ilke ve kurumsallaşmalarla daha yaşanılabilir kılınmak için devreye sokulmuş olan araçlar olduğunu ima etmektedir.

Sinema filmi de, bilindiği gibi, kültür endüstrisinin en yaygın araçlarından birisini teşkil etmektedir. Sinemayı diğerlerinden ayıran en önemli özelliklerden bir tanesi ise, estetik kaygının önemli bir rolünün olmasıdır. Bu onu, bir medya aracından daha çok, estetik ürün olarak değerlendirmeye sevk etmektedir. Fakat acaba sinema, kendi süreksizliği içerisinde seyircinin mevcudiyetine sayg1 duyan salt bir araç mıdır yoksa, seyircileri kendi varoluşu için araçlar olarak gören bir yapı mıdır? Baudrillard için sinema filmininin, insanların karşısında yer almasıyla birlikte çerçeve ortadan kaybolmakta, film onları içeriye -süreksiz, az sonra bitecek olan- sanal bir hayata davet etmektedir (Baudrillard, 2010b, s. 30). Gündelik hayattaki gerçekliklerin olduklarından daha "gerçek" olarak sunulduğu bu sanallıkta, insanla sinema filmi arasında ortaya çıkan fenomen, "rezonans"' terimi ile ifade edebilir (Postman, 1994, s. 26 vd). Zaman ve uzamda nispeten sabit olan insan, sinema filminde, sunulanın frekansına doğru çekilmekte, özünde kişiliği ile uyuştuğu tartışmalı olan bu sürece gönüllülükle katılmaktadır. Gerçeklikle ilgili olmadığı durumlarda hatta gerçekliğin hilafına, duygular harekete geçirilmektedir. Bundan da öte rezonans, duyguların ele geçirilmesine göndermede bulunmaktadır. Gerçek olmadığ 1 bilinmesine rağmen duygulu bir anda gözyaşı döküldüğü, öfke patlamasının yaşandığı ya da aşırı bir sevincin duyulduğu, empatinin doruk noktasına ulaştığ 1 an, rezonans halini ifade etmektedir. Şüphesiz, duyguların evrildiği bu süreçte, değerler de yeniden inşa edilmektedir. Zira, değerlerin oluşması -en azından geniş halk kitlesi için- saf teorik aklın bir edimi olmaktan çok, doğasının belirlenmesinin oldukça zor olduğu -kelimenin modern olmayan anlamıyla- psikolojik süreçlerde ortaya

1 Rezonans, birbirinden farklı frekanslara sahip iki ayrı sistemde, birinin frekansının diğeriyle çakışmasını ifade eden terimdir. 1940 yılında yapılan Tacoma Narrows Köprüsü’nün frekansı, rüzgârın frekansı ile eşitlenince rezonans gerçekleşmiş ve bu titreşime dayanamayan köprü yıkılmıştır. Bununla ilgili bilinen bir diğer örnek de, birbirlerine yakın duran (uzamsal bir bağıntıya sahip) iki gitardan sadece birisinden perdeye basılarak çıkan notanın diğer gitardan da elde edilmesidir. 
çıkıyor görünmektedir. Üstelik, rezonans halinde sinema filmi (modernite) ile birey arasında tek yönlü bir ilişki bulunmaktadır ve tek başına film tarafından işletilen bu kanal, bilinçlilik halinin ötesinde aktarımlar için bireyin ruhunda bir açılı̆̆ı da meydana getirmektedir.

Medya araçları ile ilgili söz konusu durumun yanında, etki gücü, kitlesel ve diğer din eğitimi öğretim araçlarıyla kıyaslandığında ekonomik oluşu ve diğer taraftan da din eğitiminin misyon ve vizyonu göz önünde bulundurulduğunda, sinemanın (TV filmleri de dahil olmak üzere) din eğitiminde bir öğretim aracı olarak kullanımı konusunda artan bir eğilimin oluştuğu gözlemlenmektedir. Ergenlikle birlikte azalan ebeveyn ve öğretmen otoritesini sinema ve sinema starları ile tahkim etmede ve duyguyu transferindeki başarısı sebebiyle duyuşsal hedeflerin kazandırılmasındaki gücü, sinemanın başlıca avantajı olarak görülebilir. Sinemanın eğitsel bir materyal olarak kullanıldığ takdirde öğrencilerin din derslerine katılımının arttı̆̆ının tespit edilmesi bunu göstermektedir. Yine de hem "dünyevi içerikli" filmlerin "dini içerikli" filmlerden daha fazla ilgi çekici bulunması hem de "dini içerikli” filmlerin inanma üzerinde etkisinin olmadığının tespit edilmesi (Coşkun ve Saraçlı, 2015, s. 125-126), sinema gibi bir aracın, işlevsellik bakımından daha çok metafiziksel ya da en azından kültür eleştirisi açısından değerlendirilmesi gereğine işaret etmektedir. Alan araştırmacıları da doğal olarak bu uygulama avantajlarını dikkate almaktadırlar -ki, kültür endüstrisi içerisinde her ne kadar önemli olsa da, din eğitimi uygulamaları için ikincil bir öğretim aracı olmakla sınırlıdır. Bununla birlikte sinema ve din eğitimi arasındaki ilişkiyi inceleyen başka araştırmacılar, sinemayı bizatihi sorunsallaştırmak yerine onun içeriğinden kaynaklanan sorunlarla ilgilenmektedirler: örneğin, "yerli bir yapım olması ve kültürel değerleri aktarmayı hedeflemesi bakımından başarıllı" görülürken "batıl inanç ögelerine yer veril[mesi] dini konularda yanlış anlaşılabilecek sihir-büyü ve olağanüstü güçlere çok fazla vurgu yap1l[masl]" olumsuz etkisi olarak yorumlanmaktadır (vurgu bize ait. Yorulmaz ve Tanrıverdi, 2015, s. 49; Yorulmaz, 2013b, s. 446). "Olumsuz değerler" ise kültürel farklılıkların doğal sonucu olarak görülebilir (Korukçu, vd, 2015, s. 81). Konu ile ilgili atılacak bazı adımlar da, öyle görünüyor ki, karşılaşılan sorunların çözümünde yardımcı olabilir: "Din öğretimi alanında filmlerin yeri, işlevleri, nasıl seçileceği ve kullanılabileceği konularında öğretmenlere hizmet içi eğitim çalışmaları yapılabilir” (Korkmaz, 2015, s. 107).

Sinema ve din ilişkisini araştıran çalışmaların belki de en önemli handikabı, bulgunun, bulgunun kaynağının ve bulgunun anlamının, araştırma nesnesinden 
elde edilmesidir. $\mathrm{Bu}$, sosyal bilimler araştırmalarının istatistiksel tekniklerle bulguya ulaşması ve yorumlanmasıdır; dolayısıyla ham verilerin değerine dair bilginin, yine kaynakta verili olduğu ilkesinden hareket edilmektedir. Böylece açık-seçik kavramlara zaten sahip insanların eğitilmesi ve açık-seçik kavramlardan yoksun olanların ifadelerinden ilke alınması şeklinde bir çelişki ile yüz yüze gelinmektedir; dolayısıyla bu çalışmaların hem metafiziksel hem de hermenötik olmak üzere çifte bir sorunla baş etmeleri gerekir. Bu sorunlar, o kadar derinlerde işlemektedir ki, moda haline gelmiş araştırma yöntem ve teknikleriyle üzerine örtmek mümkün değildir. Konunun teknik yönüne odaklanan bu değerlendirmenin yanı sıra, bir araç olarak sinema, Batı uygarlı̆̆ının bir parçası durumundadır ve onun doğasında barındırdığı dezavantajlarının farkında olunarak kullanılması gerekmektedir. Bu nedenle özellikle de, modern dünyanın tümel eleştirileri oldukça önemlidir. Yaklaşık olarak iki yüzyıllık bir süreç ve bu sürecin beraberine getirdikleri, pek çok düşünür tarafından inceleme konusu edilmiş ve çeşitli kuramlar, düşünce dizgeleri üretilmiştir.

Baudrillard, düşün hayatı boyunca yazmış olduğu çok sayıdaki eserinde, genel olarak bir kültür eleştiri kuramı geliştirmeye çalışmıştır. Karl Marx ve Marshall McLuhan gibi kişilerden etkilenmiş ve sinemanın yanında edebiyat, televizyon, Disneyland gibi eğlence merkezleri ve AVM'ler başta olmak üzere estetik ve tüketim kültürünün birbirine karıştığı alanları inceleme konusu yapmıştır. Bununla birlikte Baudrillard'ın kültür eleştirisine dair kuramı, epistemolojik düzlemden daha çok retorikle inşa edilmiştir (Altun, 2006, s. 297). Onun metaforları çokça kullanması, simülasyon evreni hakkında söylediklerini belirsizleştirse de bu tavır, simülasyon evreninin göndergelerden yoksun göstergelerden meydana geldiği postülatı ile uyumludur; zira göndergelerin yokluğu nedeniyle simülasyon evreni, sadece 'bir şeye benzemek'le tarif edilmeye izin vermektedir. Başka bir deyişle, epistemolojik bir analiz iddiası, göndergelerin yokluğu nedeniyle, kendi kendini yok edecektir.

Baudrillard, sinemayı analizlerinin konusu haline getirdiği pek çok açıklamada bulunmuş olmasına rağmen, bu sorunsalla münhasıran ilgilendiği bir eser kaleme almamıştır. Buna bağlı olarak onun sinema ile ilgili açıklama ve eleştirileri, neredeyse bütün eserlerine dağılmış haldedir. Söz konusu açılama ve eleştiriler, ekonomi politik gibi daha kökensel eleştirilere bağlanmıştır. Her bir konu başlığı, simülasyon evreninin birer modeli ya da geleneksel dünya ile karşıtlığın biçimleri içerisinde belirtilmeye çalışılmıştır.

Simülasyon kuramının toplumumuz açısından anlamı ve değerine gelince, simülasyonun, dinamiğini kendi içinden alarak değişen Batı toplumunun bir 
betimlemesi olduğu açıktır. Dolasıyla sinema gibi bir simülasyon modelinin de kendi evreni içerisinde bir tutarlılığı bulunmaktadır. Bütünüyle Batı uygarlığ 1 özelliklerini yansıtmayan başka bir toplumda simülasyon modellerinin anlamı ve etkileri, şüphesiz bazı soru işaretlerini ve daha fazla oranda belirsizlikleri haizdir. Zira Türk toplumu, tam olarak modern ya da tüketim toplumu olarak betimlenmeye izin vermeyecek özellikleri bünyesinde ihtiva etmektedir. Bununla birlikte Türk toplumu, uzun bir zamandan beri Batılılaşma serüveni içerisinde bulunmaktadır ve Baudrillard'ın tezlerini doğru kabul ettiğimizde, heterojen bir düzlemde de olsa, onun simülasyon evrenine entegre olduğu söylenebilir. Çünkü tam ya da özsel olarak modern olmadığımız gibi, geleneksel bir toplum olduğumuzu söylemek de, en az ilki kadar tartışmalı bir varsayımdır. Ne var ki, modernitenin toplumumuz içerisinde ortaya çıkıp gelişmemiş olması, onu olduğu haliyle betimleme çabalarını olumsuz etkilemektedir. Moderniteye dışardan yapılan eleştiriler, -tıpkı Batı'daki Müslüman dünyaya dair çalışmalarda olduğu gibi- yüzelsel ve ideolojik olma ihtimalini en başından itibaren taşımaktadırlar. $\mathrm{Bu}$ da, içerden yapılan eleştirileri daha önemli hale getirmektedir. Dolayısıyla tüketim fenomenlerinin ve nesnelerinin üretiminde büyük ölçüde Batıya bağım11 olduğumuz gerçeği göz önünde bulundurulduğunda, Batı uygarlığını kendi bütünlüğü içerisinde değerlendiren çalışmaların söz konusu uygarlığın etkilerini daha doğru kavrayabildiklerini söylemek yanlış olmayacaktır. Diğer taraftan Baudrillard, araştırma konusunu tikel bir olgu ya da fayda-zarar ilkesine bağlı olarak ele almamakta, onu yarı-ontolojik bir sorunsal haline getirmekte ve buna bağlı olarak normatif yargılarda bulunmaktadır. Onun bu çabası, Batı kaynak11 değer, olgu ve araçların değerlendirilmesinde özgün bir katkı sunmaktadır. Özellikle din eğitimi gibi değişkenlerin çok sayıda olduğu ve dinin kendisiyle doğrudan ilgili olduğu bir konuda dikkatleri, sorununun ilkesine yönelttiğinden, daha temelli kavrayışlara imkân tanımaktadır. Din eğitiminin hem bir disiplin hem de farklı disiplinlerin ve kurumların iştirak ettiği genelleşmiş bir pratik olması, bütüncül değerlendirme biçimlerinin daima eleştiri kıstası alınarak göz önünde bulundurulmasını zorunlu kılmaktadır. Din eğitimi bilimi, aşkın bir gerçeklik olarak dini kuşatamayacağ için din rasyonelleştirilirken bütünlük ve tutarlığını korumak adına dinin pratik veçhesine odaklanmaktadır. Bu yoğunlaşmanın sonuçları, kültür tarafından gizlenir -zira kültür, kendini evrensel bir gerçeklik olarak sunar- ve ancak bu örtüyü ya felsefe ya da eleştirel kuramlar kaldırabilir. Aşkınlık ile fenomen arasında daimi bir uyum aranamayacaksa, o halde aradaki boşluk hem aşkınlığın yaşantıya dönüşmesini hem de disiplinin yapısını olumsuz etkileyecektir. Diğer taraftan birbirine koşut bir şekilde iler- 
leyen söz konusu bu tikel-tümel diyalektiği, birinin diğerini aşındırmasıyla sonuçlanacaktır. Zira disiplinin teorisi, bu teorinin sınırlarını aşarak edimselleşen uygulama tarafindan çelişkiye düşürülürken uygulama da bir teorinin bütünleştirici ilkeselliğinin yokluğunda, salt bir yararlılık bağlamında değerlendirilecektir. İlki, usulünün yönetemediği bir eylemsellik; ikincisi, bütünlüğü olmayan bir uygulama çokluğudur. Her iki durum da, özünde aşkın bir gerçeklikle ilgili olan din eğitimi, bir maddilik içinde yani fayda-zarar ilişkisinde sınırlı kalacaktır. $\mathrm{Bu}$ bakımdan sinema, bir araç olarak tikelliğiyle din eğitimine kullanılacağ onun tümel olma vasfını taşıyan bir teorinin ilkelerle eleştirilmesi gerekmektedir. $\mathrm{Bu}$, benimsenen teorinin mutlak doğruluğunu iddia etmek değildir; aksine mutlak doğru bir teorinin olamayacağı gerçeğinin doğal bir sonucudur. Genelde medya araçları özelde sinema, din eğitimi için bir araç olarak işe koşulduğunda, dinin aşkınlığıyla din eğitimi biliminin rasyonelliği arasında ilişkinin mahiyeti değerlendirilmek istenirken, ya felsefeye ya da eleştirel kuramlara başvurmak gerekecektir. Ne var ki din eğitiminin metafiziksel temellerini ortaya koyan felsefi bir söylem bulunmamaktadır. Üstelik eleştiri kuramları, bu tür araçlarla aynı modern kökenden türediği için onların konfigürasyonu hakkında ayrımlara ulaşma konusunda avantaja sahiptir.

Çalışmada, Baudrillard'ın düşünceleri üzerinden sinemanın bir öğretim arac1 olarak kullanılabilmesinin imkân ve sınırlılıklarını tartışmak amacıyla önce onun simülasyon evreni kuramı açıklanacak, daha sonra sinema ve din eğitimi ilişkisi değerlendirilecektir.

\section{Simülasyon Kuramı}

Baudrillard'ın düşünce sisteminin ironik tarafı, modern dünyayı eleştirmek için hiç de modern olmayan masallara başvurmasıdır. Aynı zamanda handikap gibi görünen bu edimle o, simülakrı ve simülasyonu en kestirme ve en 'açık seçik' şekilde açıklamayı amaçlamaktadır -bu durum, ironiye bir de paradoks eklemektedir. Bilindiği gibi masallar, gerçeklikle sorunlu ilişkileri olan anlatılardır; daha doğrusu onlar, bir gerçeklik krizi içerisindedirler ve ancak bu krizle 'var' olabilmektedirler. Dahası, bir anlamlandırma biçimi olsalar da onlar, bilinçdışının ya da muhayyile yetisinin özgürleşmesinin gerçekliği tahrip eden ama aynı zamanda cezbedici tezahürleri olarak da görülebilir. Bununla birlikte geleneksel toplumlar, masalların ve mitlerin yaygınlığına rağmen masalların dünyasında yaşamamaktadırlar- düşsel/mitik dünyanın onları çepeçevre kuşattığını kabul 
etsek bile bu böyledir- çünkü masalın/anlatının² inşa ettiği evrene simetrik, gerçek nesnelerle ilişki kurabildikleri bir gerçeklik evreni de bulunmaktadır. ${ }^{3}$ Her iki dünyayı yaşayabilme imkânına sahip olan geleneksel insan, bu sayede birisine mahkûm olmaktan kurtulmaktadır. O halde masalla simülasyon evreninin arasında nasıl bir ilişki bulunmaktadır? Simülasyon evreni, mantık kurallarından azade olması, kendi geç̧ekliğinin kaynağının bizatihi kendisinin olması gibi nedenlerden dolayı masallarla aynı zemini paylaşmaktadır. Ne var ki, masallar gerçek evrene komşu bir evren iken simülasyon evreni, kendisi üzerine kapanmıştır.

Baudrillard simülasyonu, "bir köken ya da gerçeklikten yoksun gerçeğin modeller aracılığıyla türetilmesi” ifadesiyle açıklamaktadır (Baudrillard, 2014, s. 13). O, benzerlik ilkesi üzerinden şeylerin yerini alan imajlara göndermede bulunmaktadır (Pawlett, 2007, s. 71). Simülakrın hakikatle/gerçeklikle bir ilişkisi bulunmadığı gibi o, gerçeklikle taban tabana zıttır. Fakat bu zıtlık dahi, bir göndergeden yoksundur -aksi takdirde hiç değilse diyalektikle simülasyondan çıkılabilirdi. Herhangi bir kavramın, ideolojinin veya sistemin karşıt kutbuna yerleştirilmesine izin vermemesi, herhangi bir yörüngeye oturtulmasını engellemekte, herhangi bir çekim kuvvetine veya ilişkiler ağına tabi olmamasını sağlamaktadır. Baudrillard, bunu şu şekilde açıklamaktadır:

"Tanrı bile simüle edildikten, Tanrıya olan inanç, göstergelerine indirgenebildikten sonra gerisini varın siz düşünün! İşte o zaman bütün sistem yer çekiminin etkisinden kurtulmuş bir kütleye, devasa bir simülakra dönüşmektedir. Bu gerçek dışı bir şey değil bir simülakr olup göndergeden yoksun ve nerede başlayıp nerede bittiği bilinmeyen, hiçbir şeyin durduramadığı bir kapalı devre içinde, gerçeğin değil yalnızca kendi kendinin yerine geçebilen bir şeydir” (Baudrillard, 2006, s. 20).

Göstergeler, sınırsız bir çeşitliliğe sahip olarak etrafımızı kuşatmıştı;; Tanr1 da ancak bir gösterge olarak kendine yer bulabilmektedir. Bütün anlamların kaynağı, anlam ilişkilerinin sabitesi olarak Tanrı dahi, simülasyonda salt bir gösterge olarak vardır. Tanrıya ilişkin söz konusu bu yapısal durum, gücünü kendi içinden alan, kendine özgü bir mantıkla işleyen bir mimariye karşılık gelmektedir. Arz'1 kaplamış olan bu mimari, birbirine eklemlenmiş gerçeklik kriz-

2 Anlatıyı, örneğin Paul Ricoeur gibi, geniş bir anlam yelpazesi içerisinde değil, mitik bir bağlantı dolayıminda anlamaktayız.

3 Claude Levi-Strauss ve Mircea Eliade'ın çalışmaları, geleneksel toplumların kendine has rasyonelliğini oldukça etkileyici bir şekilde dile getirmektedir. Ayrıntılı bilgi için bknz. Eliade, M. (2003). Dinsel İnançlar ve Düşünceler Tarihi I, çev. Ali Berktay, İstanbul: Kabalcı Yayınları; Eliade, M. (2009). Dinsel Innançlar ve Düşünceler Tarihi II, çev. Ali Berktay, İstanbul: Kabalcı Yayınları; Levi-Strauss, C. (2013). Mit ve Anlam, çev. Gökhan Yavuz Demir, İstanbul: İthaki Yayınları. 
leriyle şimdi ve burada'yı yapay olarak içinde barındırmaktadır. Baudrillard, gerçeklikle simülasyonun birbirinden başka oluşunu açıklamak için Borges'nin masallarından bir parçayı kullanmaktadır. Masal şöyledir:

"O imparatorlukta haritacılık sanatı o denli mükemmelliğe ulaşmıştı ki, tek bir eyaletin haritası bir şehri ve imparatorluğun kendisinin haritası bütün bir eyaleti kaplıyordu. Zaman içerisinde, bu ayrıntılı haritalar biraz eksik bulundu ve haritacılık okulu, imparatorlukla bire bir ölçekte bir imparatorluk haritası geliştirdi, öyle ki harita, noktası noktasına gerçeğiyle çakışıyordu. Haritacılık bilimine daha az önem veren sonraki kuşaklar, bu boyuttaki bir haritanın kullanışsız olduğuna karar verdiler ve biraz saygısızlık da ederek onu güneş ve yağmur altında yıpranmaya terk ettiler. Batı çöllerinde haritanın yırtılmış parçaları bugün bile bir hayvana ya da bir dilenciye barınak olabiliyor; coğrafya biliminden tüm ulusa kalan yalnızca budur" (Borges, 1993, s. 123).

Masal, hem ontolojik hem de aksiyolojik bakış açısını aynı anda sunmaktadır. İlk olarak o, modern kültürün yayılmasına koşut bir şekilde, giderek gerçek dünyayı birebir simüle edebilmesine karşılık gelmektedir. Burada harita, bir işaret olma rolünü aşarak, hareket noktasını, yolu ve varış noktasını; araç, süreç ve amacı kendinde toplamıştır. Gönderge iptal olmuştur; anlam, bilindiği anlamıyla karşıllaştırıldığında, yokluğa mahkûm olmuştur. İnsan da zorunlu olarak, harita üzerinde bir değişken haline gelmiştir. Dikkat çeken bir diğer nokta da, iddia edilenin aksine olgunun antropolojik olduğu iddiasıyla çelişmesidir. Bilindiği gibi, aşkın olanla irtibatını kesmiş olması nedeniyle, modernitenin antropolojik bir olgu olduğu ileri sürülmüştür. Fakat üç boyutlu bir harita, beden ve ruhlar için bir mekân sağlamaktan daha çok değişkenlerin maddilikleri için bir uzam gibi görünmektedir. Diğer taraftan masal, Baudrillard'ın sisteminde ahlakın düğümlenip kaldığı yere de işaret etmektedir. Burada, üretim-tüketim ilişkilerinin insanın varoluşuna yönelmesiyle ahlakın da artık yok olup gittiği ve ahlaki olarak nitelendirilen tutum ve davranışların hakikati daha fazla perdelemek ve insanı daha fazla evcilleştirmek için dayatıldığı da ima edilmektedir. Baudrillard'ın bu iması, simülasyonun hakikat dünyasından ne denli ayrı olduğuna işaret etmektedir.

Baudrillard'a göre, bir gerçekliğin yerini alan ve onun işlevini görebilen hatta gösterge düzeyinde ondan daha kusursuz/hipergerçek olan anlamına gelen simülasyon evreni, bir zar gibi hakikat dünyasını kaplayarak onun yerini almıştır (Baudrillard, 2010a, s. 23). Bu kültürel evren otantik bir kökene sahip olmadığ gibi, herhangi bir ereğe koşullanmış da değildir. Ne iyilik veya adaleti ne de iyi 
kavramı ile ilgili başka herhangi bir ilkeyi gerçekleştirme amacı gütmektedir. Bütün derinliğini, bakışları illüzyonlarla sınırsızca yansıtan mutlak yüzeyselliğinden alan bu evren, ancak gerçek dünyaya ait nesneler veya onlara ilişkin anlatılar üzerinden algılanabilmektedir. Bu nedenle Baudrillard, simülasyon evrenini açıklarken sık sık karşılaştırmalara başvurmaktadır. Karşılaştırma imkânı veren en önemli örneklerden birisini Disneyland teşkil etmektedir (Lane, 2001, s. 86). Simülasyonun en etkileyici modellerden birisi olan Disneyland, simülakr katmanlarının kusursuz bir birleşiminden oluşmaktadır. Çeşitli kurgular (ki bu kurgular, korsanlar gibi orijinallerin dönüştürülmesidir) bir illüzyon ve fantazma oyunudur. Korkunun, çelişkilerin ve gizemlerin karışımından oluşan Disneyland, müşterilerine dinin verdiğine benzer bir kolektif haz vermektedir. Evrenin bir bütün olarak içine çekildiği bu karadeliklerde yeniden inşa edilen metastazik 4 "şeyler", çeşitli araçlarla (filmler, çizgi filmler, reklamlar) kutsanmakta ve çoğaltılarak/kopya edilerek dolaşıma sokulmaktadır (Baudrillard, 2014, s. 27). Disneyland, gerçeği simetrik bir şekilde içe yansitarak onu ne gerçek ne sahte olarak nitelendirilebilecek bir kurguya dönüştüren bir simulakrdır. Diğer bir örnek de II. Ramses'in mumyasıdır. Kültürel birikimin ama aynı zamanda simgesel düzenin varlığının ve başarısının en somut örneklerinden birisi olan II. Ramses mumyasının binlerce yıldır varlığını koruyabilmesine rağmen, simülasyon düzeninin sırrı ifşa etmesi ve simgenin doğasını bozması sebebiyle, her türlü bilimsel araca rağmen bozulması 'engellenememektedir' (Baudrillard, 2014, s. 23). Mumyanın görünürde ilerleme mantığına tersyüz edecek bir biçimde bozulması, simülakr ile hakikatin telif edilemez farklılığının diğer önemli işaretidir.

Baudrillard'a göre, metafiziksel evrenden simülasyon evrenine geçişle şeylerin algılanma biçimi arasında bir koşutluk bulunmaktadır. İnsanlık, metafiziksel dünyada Tanrı ya da onun yerini alan başka bir aşkınlığa bahşetmiş olduğu hayatın karşılığında, ödenmesi mümkün olmayan borcunu sembolik olarak ödeme çabaları içerisinde olmuştur. Özellikle kurban motifi, bu durumu en somut şekilde göstermektedir. Bütün mütekabiliyet mantıklarına meydan okuyan söz konusu girişim, içerisinde yaşadıkları dünyayı aşkın olana bağlayarak bir anlamda onu da aşkınlaştırmaktadır. Buna karşın dünyanın 'nesnel' yasalarla anlaşılmaya başlanması, bir bakıma başarı ve teşekkürü de içe yöneltmiştir. Böylece doğal olanın yok edilip gittiği, yerine yapay bir dünyanın inşa edildiği dönem başlamıştır. İllüzyonlar nedeniyle sabitenin ve doğal olarak anlamın yokluğu, geri dönüşü imkânsız kıldığından, modern insana tek çıkış yolu olarak yapaylığı

\footnotetext{
4 Metastaz, kanserli hücrelerin bulundukları doku dışına yayılmalarına karşılık gelen tıbbî bir terimdir.
} 
olabildiğince ileri noktaya taşıyarak sanal dünyayı kurmak görünmüştür. Hakikatin kendini hatırlattığı her ana onun üstünü örtecek yeni simülakrların üretilmesiyle karşılık verilmiştir (Baudrillard, 2005c, s. 30-31). Baudrillard, şeylere otantiklik kazandıran metafiziksel dünya ile bağın kopmasının, herhangi bir şey görünümüne sahip olan bir şeyin aslında o şey olmadığını ima etmektedir. Geriye sadece gösterge ve üretim için malzeme kalmaktadır (Bayrı, 2011, s. 96). Görsel süreklilik arzusuyla simülakrlar, gözlerimizden ruhumuza doluşmakta ve gizlerle sarılı bütün kutsalları donuklaştırarak sergilenmek üzere etnolojik, antropolojik vs. bir nesne haline dönüştürmektedir. Simülasyon düzeni, varlığ1nı devam ettirebilmek için karşılaştığı her kavramı, her nesneyi ve her olguyu taşlaştırmakta ve kendisi içerisinde eritmektedir.

Geçmiş zamanlarla olan bütün benzemezliğine rağmen simülasyon evreni, bir anda oluşmuş değildir. İnsanlığın tarihsel yürüyüşü, bu sonuca adım adım yaklaşmış ve ilk defa Batıda vücut bulmaya başlamıştır. Simülasyonun tarihini açıklamak için Baudrillard, insanoğlunun serüvenini dört temel evreye ayırmaktadır: doğal evre, ticari evre, yapısal evre ve fraktal evre. Doğal evre, doğal bir gönderene sahipken değer de buna uygun olarak dünyanın doğal kullanımı ile ilişkili iken ticari evreye genel bir mütekabiliyet yasası egemendir (Baudrillard, 2005c, s. 29). Yapısal evrede ise, şeyler kodlar şeklinde üretilmekte ve modellerle somutlaşmaktadır (Kellner, 1989, s. 21). Kodların gerçekte var olmamalar1, "kültürel" dünyanın sanal olmasına neden olmaktadır ki bu sanallığın temel özellikleri: içe gömülme, içkinlik ve anındalıktır (Baudrillard, 2010a, s. 29). Son evre olan fraktal evrede ne bir gerçek kod ne de gönderge vardır (Walters, 2012, s. 29). Değerler, bireyin tespit edemeyeceği kadar çok hızlı olarak bütün yönlere doğru yayılmaktadır. Artık, "ne doğal ne genel bir denge vardır, gerçek anlamda sözü edilebilecek bir değer yasası yoktur artık: bir tür değer salgınından, değerin genel metastazından, rastlantısal bir şekilde hızla çoğalma ve dağılmasından başka bir şey yoktur" (Baudrillard, 2010a, s. 12). Üzerinde ittifak edilebilecek bir genel yasa olmadığı için, değer diye bir mefhumdan bahsetmek mümkün olmamaktadır (Baudrillard, 2005b, s. 24).

Dört evrenin son ikisine üç simülakr düzeni hâkim olmuş haldedir: Rönesans'tan Sanayi Devrimine uzanan kopyalama, sanayileşme ile özdeşleşen üretim ve integral üzerinde yükselen simülasyon (Baudrillard, 2008, s. 87). Modern dönem, aşkınlığın tamamen bertaraf edilmesiyle bir simülasyona dönüşmüştür (Güzel, 2015, s. 68). Bir önceki döneme (illüzyon dönemi-simülasyonun ilk evresi) özgü çizgisellik ve diyalektiğin son bulduğu sistemde, olgu ve olayların 
başlama, gelişme ve sona erme süreçleri izlenmeye çalışıldığında, simülakrın sebep olduğu yanılmasa dolayısıyla kesinliğin var olmadığını, bu olgu ve olayların bütün paydaşların işine yaradıktan ve onları memnun ettikten (hazzı ürettikten ve paylaştırdıktan) sonra, bütün anlam kombinasyonlarına dağılarak bir anlamda ortadan kaybolduklarını iddia etmektedir. Çünkü simülasyon düzenini oluşturan alt sistemler ve bu alt sistemlere ait gerçeğin üzerinde temellendiği mantık, simülasyon tarafından egemenlik altına alındığ için, modeller aracılığ 1 ile somutlaşmış haldedir. Modeller, kaotik bir düzende hareket etmektedir ve bu nedenle izledikleri sabit bir rota bulunmamaktadır (Gane, 1991, s. 98). Olgu ve olayların, modellerden hareketle anlaşılmaları, dahası tek bir olgunun pek çok modelle açıklanabilmesi, kaçınılmaz olarak çelişkili olanları dâhil olmak üzere, sayısız yorumun ortaya çıkmasına neden olmaktadır. Ki bu sayede herkes kendi hakikatine sahip olabilmekte, herkes haklı olabilmektedir. Bununla birlikte bu belirsizliğe son vermek, artık imkânsız görünmektedir. Zira o, problemlerin çözümünü temsil eden bir simgeye dönüşmüştür. Özellikle bilim aracılı̆̆ıyla nesnellik kriterinin genel bir yaklaşım olarak benimsenmesi, illüzyondan arındırılmış "gerçekliğin" ele geçirilerek insanlığa dayatma amacına yöneliktir. Batı toplumu, Rönesans'tan beri 'rasyonellik' tarafindan biçimlendirilmektedir. Bununla birlikte, Baudrillard'a göre ne nesnellikten ne de öznellikten bahsetmek mümkündür. Bu iki kavram, gerçekliğe cepheden bakma, ona katılmadan onunla yüz yüze gelme alışkanlığından kaynaklanan ikili bir yanılsamadır (Baudrillard, 2005c, s. 37 vd). Gerçekliği olduğu gibi anlama iddiasında olan rasyonel çaba, simülakrlar tarafından bertaraf edilmektedir çünkü simülasyon düzeninde, ayna ve yansıttıkları arasında geçerli bağıntılar bulunmadığından, aralarındaki spekülatif ayrım daha da derinleşmektedir. Özne ve nesne, sabit bir noktaya bağlı olmadığından muhkem bir dayanak noktasından yoksun kalmakta, dolayısıyla özne ve nesnenin sürekli yer değiştirdiği bir oyuna dönüşmektedir (Baudrillard, 2005c, s. 39-40).

Kadim dünyanın anlamlandırılma sürecinde başvurulan metafiziğe ve metafizikleştirilmiş dünyaya "tahammül” edilemediği için, bir yanımızı hazlarla memnun etmesine rağmen -bu durum, Freudyen bilinç dışı kuramıyla oldukça benzerlik göstermektedir- diğer yanımızı rahatsız etmesine bağlı olarak bu illüzyonun üzerinin örtülmesi ve yokmuş gibi yapılması için anlam simülakrlarıyla sahte aşkınlıklar üretilmeye çalışılmaktadır. Bu ise, Baudrillard'a göre, hakikatin kendisini değil, hakikatin yokluğunu gizlemeyi sağlamaktadır. İcat edilen hipergerçek, tam olarak buna işaret etmektedir (Baudrillard, 2005c, s. 30). Artık ütopyalar gerçekleşmiş olduklarından, hipergerçeklik içerisinde ye- 
niden yaşanmak durumundadır. Bütün illüzyonlar, düşler, hayaller vs. çeşitli araçlarla sonsuz sayıda yeniden üretilerek yaşanmaktadır. Bunlar -yüzeyler olarak- moda, TV programları, sinema, AVM'ler üzerinde gerçekleşmektedir (Baudrillard, 2010a, s. 10).

Simülasyon evreni, aşkınlıkla bağını koparmış olması sebebiyle, kendi üzerine kapanıp kapalı devre oluşturmuştur (Turan, 2007, s. 91). Bu nedenle bir gösterge olarak simülakr herhangi bir göndergeye sahip değildir (Koch \& Elmore, 2006, s. 562; Pawlett, 2007, s. 71). T1pkı bir masal gibi anlamını yutmuştur; ondan farklı olarak masala eşlik eden simetrik bir hakikat dünyası olmadığı için, her 'şeyi' nötrleştiren devasa bir kara deliği andırmaktadır (Baudrillard, 2014, s. 14). Dünyanın aşkınlıkla bağı bir kez kesildiğinde ve kutsallık gölgesini varlık âleminden çektiğinde şeyler, anlamdan soyutlanmakta ve bu halleriyle taşınmaz bir yüke dönüşmektedir. Hakikatin geri çekildiği dünyaya, görünümler dünyası demek bile pek mümkün görünmemektedir. Zira Nietzsche'nin ifade ettiği gibi, hakikatle birlikte (Tanrının ölümüyle), görünümler dünyası da yok olmuştur. İnsani olan her şeyi yitiren şeyler, yorumlardan; var olduklarına delalet edecek bir izden, gölgelerinden yoksunlaşmaktadırlar.

Zaman ve mekân da her şeyi dönüştüren dijitallikten nasibini almış haldedir: "Olaya özgü tarihsel zaman, duygu ve tutkulara özgü psikolojik zaman, yarg1lama ve iradeye özgü öznel zamanın karşısına alaycı bir dille, 'gerçek zaman' dediğimiz sanal zamanla çıkılmaktadır” (Baudrillard, 2005c, s. 28-29). Yani, Baudrillard'a göre, zamanın kaybolması aşkınlı̆̆ın kaybolmasına koşut olarak gerçekleşmiştir. Fetişleştirme, dışsallığı ortadan kaldırırken içselliği de buharlaştırmakta ve gerçek zaman, zaman kategorilerini yerinden ederek zamanı da yok etmektedir. İletişim ve enformasyon, fonksiyonlarını yitirdiği için daha doğrusu fonksiyonları simülasyon düzeninde sonsuzca yansıyıp dağıldığından dolayı, geleneksel anlamını göz önünde bulundurduğumuzda anlamsızlaşmıştır. Özünde bir mit, ütopya ve söylencenin bulunduğu ama her durumda rastlant1sallığın hâkim olduğu toplumsalın yerine, enformasyondan öte bir propagandanın biçimlendirdiği kitle kalmıştır (Baudrillard, 2010a, s. 18). Yani toplum dahi uğradığı mutasyon neticesinde yığınlara, kalıcılığı olmayan, sürekli ayartma oyunlarına tutulan kalabalıklara dönüşmüştür (Bogard, 1990, s. 2 vd). Baudrillard'a göre kitle sosyolojik bir varlık değildir; o, metafiziksel bir kavramın etrafında örgütlenmek yerine, yani kötü-iyi, yanlış-doğru, çirkin-güzel olarak belirlenmiş bir tasavvura göre nispeten sabit bir kutup etrafında toplanmaksızın kutupsuz olmanın beraberinde getirdiği bir sınırsız kutup ihtimali içerisinde dağllmaktadır (Baudrillard, 1991, s. 10). 


\section{Simülasyonun Ayartıcılığı}

İletişim araçları üzerine çalışmalar yapan Marshall McLuhan, 'araç mesajdır' şeklinde formüle etmiş olduğu yaklaşımında, mesajı transfer eden aracın içeriği de kaçınılmaz olarak biçimlendirdiğini ileri sürmüştür (McLuhan, 2013, s. 23 vd). Buna göre kitle iletişim araçları, doğalarına koşut olarak mesajları manipüle etmektedir. Mesajın/anlamın dönüştürülme sürecinin sadece iletişim araçlarına özgü bir durum olduğunu söylemek, meseleyi dar bir alana hapsetmek demektir. İktisat bilimcisi Schumpeter'in kapitalist piyasayı tasvir etmek için kullandığı 'yıkıcı devrim' kavramı daha geniş bir çerçeve çizmektedir. Schumpeter, anlamın anlamla zihin arasını dolduran her araç tarafından yeniden inşa edildiğine ve gücüne orantılı bir şekilde dayatıldığına işaret etmektedir. ${ }^{5}$ Yani, öyle veya böyle kullanıma giren her araç, yeni bir anlamı/ anlam kombinasyonunu beraberinde getirmektedir. Değişim kritik eşiği aştığında, yol yeni bir döneme çıkmaktadır. Her yeni araç, bir öncekini ortadan kaldırırken onunla ilgili her uygulama, ifade hatta deyim ve esprileri bile yok etmektedir. Modern dönemde bu fenomen, karakteristiktir. Yani ancak böyle yaparak varlığını devam ettirebilmektedir; onu önceki evrenlerden ayıran, her şeyin fetişleştirilmesidir (Gerçi fetişizm eski kültürlerde de vardır fakat bilindiği gibi fetiş nesnesi seçildiği türün en biçimsiz, en kusurlu olanıdır. Alışılmadık derecede ilginç olan, insanları kendine çekmekteyken bugün, kusursuzluk ilgiyi kendine çağırmaktadır).

Bununla birlikte, aracın mesajı dönüştürebilmesi için bireyin/toplumun ayartılması gerekmektedir; bu sürecin toplumsal ölçekte gerçekleşebilmesi için de toplumun kitleselleşmesi. Kitleyi oluşturansa, sadece kitle iletişim araçları değildir; akla gelebilecek pek çok araç, özellikle de ticari ürünler, toplumdan pek çok kitle çıkarabilmektedir. Ayartma, göndergeden yoksun göstergenin hiçbir şeye işaret etmemesi nedeniyle mutlak bir nihilizmle özdeşleşmedir. Sınırsız derinliğini, mutlak yüzeyselliğinden almaktadır. ${ }^{6}$ Göstergenin büyüleyiciliği

5 Joseph Alois Schumpeter'ın oluşturduğu kurama göre 'kapitalizm, doğası gereği ekonomik değişim biçimi veya metodudur ve asla sabit/statik olmadığı gibi hiçbir zaman olamaz da. Üretim ve pazarlama sürecine dâhil olan unsurlar, sürekli olarak eskileri yok etmekte ve yerlerine yenilerini yaratmaktadır. Bu yaratıcı yıkım süreci, kapitalizmin temel karakteristiğidir ve kapitalizmin bağlı olduğu şeydir." (Schumpeter, J. A. (1950). Capitalism, Socialism and Democracy. New York: Harper and Brothers Publishers. p. 82-83).

6 Yüzeyin gizemini ve etkisini - ama olumlama farkılla- açıklamaya çalışan bir diğer düşünür de Deleuz'dür. Deleuze, farklı bir bakış açısına sahip olmakla birlikte, anlamın yüzeyde saklandığını ifade etmekte ve bunu şöyle açıklamaktadır: “... Çünkü Platon’da şeylerin derinliğinde, toprağın derinliğinde, İdeanın etkilemesine boyun eğenle bu etkiden kaçıp kurtulan arasında (kopyalar ve simülakrlar arasında) karanlık bir mücadele sürüp gitmekteydi. Sokrates her şeyin, kılın, kirin, çamurun bile bir İdeası var mı- yoksa hep inatla İdeadan kaçan şeyler mi var? diye sorduğunda bu mücadelenin yankısı hissedilir. Ancak Platon'da da bu şeyler tamamen gömülmüş, tamamen 
de bundan kaynaklanmaktadır. Bütün uygarlık, göstergeye yenik düştüğü için, her yerde binlerce gösterge, simülasyon modelleri tarafindan gözlerimizden ruhumuza akıtılmaktadır. Hakikatin dinginliğine, derinliğine ve iddiasızlığına rağmen simülakr kibirli, saldırgan ve oldukça akıcıdır. ${ }^{7}$ Hakikatin varlığını değil yokluğunu gizlemektedir, mükemmel bir tuzak gibi bütün anlamları yakalamakta ve hapsetmektedir.

Toplum ise ancak, gerçek bir toplumsal ilişkinin var olması ile var olabilmektedir (Baudrillard, 2009, s.74). Toplumsal ilişki de toplumsal, tarihsel vs. zıtlıkların meydana getirdiği bir toplumsal yapı, bir ideal; bu ideale ulaşma uğruna benimsenen stratejiler ve sürdürülen savaşta içerimlenmiştir (Baudrillard, 1991, s. 57; Koch \& Elmore, 2006, s. 560). Baudrillard'ın toplumun var olabilmesi için ortaya koyduğu şartlar, basit bir ilkenin varlığını kesinleştirmek içindir: kapsamlı veya dar, gelişmiş veya ilkel bir perspektif. Yani, simülasyon düzeninde olunmadığının bir kanıtı olarak anlamı garanti eden bir kusur. Hâlbuki sanal dünyada meydana getirilen imgelerin gerçek dünyaya ait olmadıklarının en belirgin işaretlerinden birisi, kusurlu ve rastlantısal olmaya izin verilmemeleridir. $\mathrm{Bu}$ dijital/sentetik

bastırılmış, cisimlerin derinliğine itilmiş, okyanusta boğulmuş değildir. İşte şimdi her şey tekrar yüzeye çıkıyor. Stoacı müdahalenin neticesi budur: sınırsız-olan tekrar yükselir. Deli-oluş, sınırsız-oluş artık uğuldayan bir dip değildir, şeylerin yüzeyine çıkar ve nüfuz edilemez hale gelir. Artık söz konusu olan, dipten kurtulan ve her yere sszan simülakr değil kendi yerlerinde ortaya çıkan ve işleyen sonuçlardır. Nedensel anlamda sonuçlar, ayrıca işitsel, görsel ya da dilsel 'etkiler'-bundan daha azı ya da çok daha fazlası, çünkü onlarda artı cisimsel hiçbir şey yoktur ve onlar şimdi tümüyle idedir... İdeadan kaçan şey yüzeye, cisimsiz sınıra yükselmiştir ve olanaklı bütün idealliği o temsil eder; ideallik nedensel ve zihinsel etkililiğinden yoksun bırakılır. Stoacılar, yüzeydeki sonuçları keşfetmişlerdir. Simülakrlar, yeraltı isyancıları olmayı bırakıp sonuçlarını/etkilerini ortaya çıarırlar (bunları Stoacı terminolojiden bağımsız şekilde 'fantazm' olarak adlandırmak da mümkündür). En derine gömülü olan, en görünür hale gelir, oluşla ilgili bütün eski paradoksların yepyeni bir gençlik içinde tekrar şekillenmesi gerekirdönüşüm (Deleuze, G. (2015). Anlamın Mantığı. çev. Hakan Yücefer, İstanbul: Norgunk Yayıncllı, s. 23-24).

7 Hakikat ve simülakrın bu karşıtlığını ve yan yana bulunmalarının olanaksızlığını Dostoyevski, Hz. İsa ve bir kardinal üzerinden etkileyici bir şekilde açıklamaktadır. Hikâyeye göre, Engizisyon mahkemelerinin İspanya'da en çok mesai yaptığı yani merhameti sonsuz Tanrıyı inkâr edenlerin canlı canlı yakıldığı dönemde Hz. İsa evlatlarını görmek için gökler âleminden yeryüzüne iner. Hiçbir şey söylememesine rağmen insanlar onu hemen tanırlar ve gözyaşları içerisinde çevresini sararlar. Tam o anda şehrin meydanından geçen kardinal, kalabalığa yaklaşır ve onunla karşı karşıya gelir. Gördüğü manzaradan hoşlanmayan kardinal, derhal kutsal muhafizlarına Hz. İsa'yı yakalamalarını emreder. Halk, bu emir karşısında iki yana doğru açılarak onu yalnız bırakır. Daha sonra kardinal, hapishanede onu ziyarete gelip her şeyi mahvettiğini ve hemen orayı terk edip insanları rahat bırakmasını söyler. "Neden bize engel olmak istiyorsun? Bize engel olmak için geldiğini sen de biliyorsun. Ama yarın ne olacağını biliyor musun? ...Kim olursan ol, hemen yarın hüküm giydirip en azılı zındık olmak suçuyla yakacağım seni. Bugün ayaklarını öpen halk, yarın biz göz işaretimle atılacağın ateşe odun taşımaya koşacak, bunu biliyor musun?" Kardinal, insanlara şeytanın ögüdünü dinlemeyip saf irade talebiyle saf özgürlüğü vererek aynı zamanda en ağır yükü yüklediğini, kendilerinin bin bir emekle ondan kalan emaneti dönüş̧ürerek temeline mucize, sır ve otorite koyarak yeniden inşa ettiklerini söyler. İnsanların yüreklerini yerinden söken korkuyla mutlu oldukları ve korkularını nasıl büyüteceklerini bildiklerini sözlerine ekler. "Tabii çalıştıracağız onları, ama işten arta kalan zamanlarını çocuk oyunlarına benzeyen şarkılar, korolar ve masum rakslarla dolduracağız. Hatta günah işlemelerine de izin vereceğiz; zayıf ve acizdirler, günah işlemelerine izin verdiğimiz için çocukça sevecekler bizi." (Dostoyevski, F. M. (2014). Karamazov Kardeşler, çev. Nihal Yalaza Taluy, İstanbul: İş Bankası Kültür Yayınları, s. 331-347). 
imgenin gerçek bir göndergesi olmadığı gibi, yokluğunun imgesi olarak karşı1lı bulacak bir negatifi de bulunmamaktadır (Baudrillard, 2005c, s. 25). Dilin sahip olduğu simgeler, semboller, mecazlar, alegoriler de cerrahi bir müdahaleyle çekip alınmakta, "negatif film şeridinin sentetik imge tarafından saf dışı edilmesine benzer bir şekilde edebi nitelikler de" sadece göstergeye yani kendine işaret edecek bir hale sokulmaktadır (Baudrillard, 2005c, s. 27).

Baştan çıkarma yine de, ancak iradenin var sayılabildiği bir zeminde mümkün olabilir. Fakat anlamın yokluğunda iradeden bahsetmek ne kadar mümkündür? Maddi olanlarda olduğu gibi irade de sentetik olarak üretilmektedir. Dolaysıyla simülasyon karşı karşıya kaldığı paradoksu böylelikle aşabilmektedir. İradeyi kullanan simülakr, bilinçdışının bütün bağlardan özgürleştirilmesiyle sentetik iradeye yönelmekte ve onu yok etmekte, böylelikle birey ve kitleyi kendinden geçirmektedir. ${ }^{8}$ Yani zannedilenin aksine uyuşturmamakta, tam tersi uyarmaktadır; iradenin en son aşamasına kadar götürülmesiyle anlam bütünüyle tüketilmekte ve tıpkı bir simülakr gibi çekimsiz, bağlamsız bir sonda durdurulmakta ve daha sonra varsayımsal bir irade fikri tekrar zihne enjekte edilmektedir (Baudrillard, 2011, s. 9-10). Özgürlük fikri, bu nedenle hayati bir öneme sahiptir. Bu nedenle en kutsal şey özgürlükmüş gibi davranılmakta ve mutlak tabu olarak kabul edilmektedir. Sistemin işleyişinde en ufak bir kuşkunun varlığ sezildiğinde göstergeler, mümkün olan en hızlı şekilde çoğaltılmakta; irade işler görünmektedir. Ta ki en kesin inanç oluşana kadar... Yani düzenin devam edebilmesi için süreç, başlangıç olmayan ama onu andıran bir başlangıçla sonlanmaktadır. Belki de, simülasyon modellerini düzenleyen tek yasa budur: 'varsayımsal bir irade, her halükarda bulunmalıdır'. Kitleleri bir iradeye sahip oldukları konusunda ikna eden şey, onların bir özne, özneler grubu veya nesne olamaması ve bu sayede güdümlendiğine yönelik şüphelerinin yatıştırılmasıdır. Baudrillard'a göre kitlelere yönelen her sondaj teşebbüsü (seçimler, reytingler, gişe rakamları, anketler) kitleler tarafindan tüketilmekte ve olduğundan başka bir şeye dönüştürülmektedir (Baudrillard, 1991, s. 21). Bu ise, sahte bir kendine güven meydana getirerek illüzyonun devam etmesine katkı sağlamaktadır. Diğer taraftan da, kitlelerin ne içten ne de dıştan sabit bir yörüngeye oturtul-

8 Macbet'in trajedisi, iradenin varsayımı ile ayartılma ilişkisinin edebi örneklerinden birisini teşkil etmektedir. Zaferin elde edildiği bir savaşın sonunda Macbeth, yolda karşılaştığı cadılardan önce Cawdor Beyi daha sonra da İskoçya Kralı olacağını öğrenir. Mevcut şartlardan dolayı bunun imkânsız olduğunu düşünürken Kralın adamları onun Cawdor Beyi olarak seçildiğini haber verirler. Kehanetler tarafindan ayartılan, sadakati ve cesaretiyle ünlü Macbeth, kral olma tutkusuna yenik düşer ve kralı öldürerek tacı gasp eder. Daha sonra cadıların yeni kehanetleriyle tekrar ayartılır. 'Íradesiyle' yaptıklarının sonuçları onu psikolojik bir hastaya dönüş̧ürür. Kendinden geçme hali- ki ölümü öncesinde gayet iyi görünür ve varsayımsal bir irade kendini gösterir, yine kehanet tarafindan hayatına son verilmesiyle noktalanır (Shakespeare, W. (2006). Macbeth, çev. Sabahattin Eyüboğlu, İstanbul: İş Bankası Kültür Yayınları). 
masının mümkün olmaması, sondajların/ayartma araçlarının hem çeşitlenmesini hem de sıklaşmasını beraberinde getirmektedir (Baudrillard, 1991, s. 25). Ayartılan kitleler, sürekli olarak bir anlam değiş tokuşuna maruz kalmaktadırlar. Güdümlenmiş kitleler, sanki düzen kurucu onlarmış ve bütün yapıyı onlar inşa et/tir/mişler gibi, stadyumvari bir kapana doldurulduklarında olayları şekillendirebilecekleri düşüncesine kapılmaktadırlar. Tarihin öznesinin kendileri olduklarını zanneden bu yığınların sahip oldukları en önemli işlev ise anlamı sürekli olarak nötralize etmeleridir. Onlar, bütünüyle şimdi ve burada'ya çakılı kaldıklarından "güncel" varlıklardır. Geçmiş ve gelecekleri olmayan kitleler, gösterge ve göndergeleri birbirinden ayırarak anlamı yok eden bir karadeliğe dönüşmüşlerdir. Olabildiğince şeffaf ve esnek oldukları için hiçbir uyarıcıya tepki verme yetileri bulunmamaktadır. Hiçbir iddialarının, söylenecek hiçbir sözlerinin olmaması, onları "mükemmel" kılmaktadır. Temsil etme kabiliyetlerini kaybettikleri için hiçbir şey yansıtmayan, dahası yansıtmak zorunda bile olmayan mükemmel bir ayna gibidirler (Baudrillard, 1991, s. 7-8). Ama yine de bu ses vermeyen yap1, çeşitli sondajlarla sürekli olarak yoklanmaktadır. İnsanların referandumlar, testler, reyting sonuçları, kitle iletişim araçları yoluyla ne düşündükleri, nasıl davrandıkları araştırılmaktadır. Simülatif düzen içerisinde [ir]rasyonel yaşayan insanların ne düşündüklerinin önemsenmesinin sebebi, tüketim çılgınlığının devam edebilmesi için hangi yeni göstergelerin icat edileceği sorusuna cevap oluşturmalarıdır. Artık istatistikler, kitleyi temsil etmektedir. Amaçlanan gösterge ve gönderge değil, göstergelerin somutlaştığı modellerdir (Baudrillard, 1991, s. 19). Kitle iletişim araçları tarafından iletilen mesajlar, kitleyi oluşturan alt gruplara özgü kodlar tarafından çözülmektedir (Baudrillard, 1991, s. 32). Baudrillard, kitlenin genel özelliklerini şu şekilde açıklamaktadır:

"Kitleler, hiçbir seçim yapmayıp, hiçbir ayrım üretmedikleri gibi tam tersine aldırmazlık üretmektedirler - aracın büyüleyiciliğini mesajın eleştirel yanına tercih etmektedirler. Çünkü büyülenmenin anlamla bir ilişkisi yoktur. Büyülenme anlamın kullanılmamasıyla doğru orantılı bir durumdur. Araç yararına mesajın ve simülasyon yararına doğrunun nötralize edilmesiyle elde edilir. Kitle iletişim araçlarının iş gördüğü düzey, işte bu düzeydir. Onların ilkesi, büyülemedir. Anlama karşı giriştikleri şiddetli saldırı; iletişimin, başka bir iletişim biçimi yararına anlama karşı giriştiği olumsuzlayıcı bir saldırı" (Baudrillard, 1991, s. 28).

Dahası anlamın nötralize edilmesiyle oluşan anlamsızlık, haz vermektedir. Fakat bu durum, yani anlamsızlaştırma, ölüm güdüsüyle motive edilmemektedir. Çünkü eğer böyle olsaydı, hayatın anlamının temayüz etmesi gerekirdi. 
Bu tavrın arkasında yatan neden, gösterge-gönderge birlikteliğine düşmanca bir karşı çıkış, "mesaja ve her türlü dilbilimsel kategori girişimlerine karşı bir alerji, bir meydan okuma"dır (Baudrillard, 1991, s. 45). Bu, insanı büyülemektedir. Büyülenmenin herhangi bir metafizikselliğe neden olmaması, tüketim simülakrları için işlev görmeleri nedeniyledir. İhtiyaçların gerçek olmaması, ihtiyaç hissetmenin bir yoksunluğa bağlı olmaması, sadece üretilen bir yoksunluk hissinin karşıllı̆ı olması anlamına gelmektedir. Yoksunluk oluşturma ve tüketim nesnelerinin üretimi simülakrların varoluşunun arkasında yatan ilkelerdir.

Simülasyon evreni, kendi üzerine kapanmış bir uzamdan oluşmuşken sinema gibi bir simülasyon modelinin din eğitiminin amaçlarına hizmet edebilmesi mümkün müdür? Eğer Baudrillard'ın simülasyon evreni teorisi, modern kültürün yetkin bir betimlemesini sunuyorsa, bu soruya olumlu cevap vermek oldukça zor olacaktır. Bununla birlikte, fiili durumda sinema gibi kitle iletişiminde 'verimli' olan araçlar, alternatif öğrenme teknikleri için gün geçtikçe daha fazla ilgi odağı olmaktadırlar.

\section{Bir Simülasyon Modeli Olarak Sinemanın Din Eğitiminde Kullanımı}

Genel olarak çeşitli enformasyon araçları ile din eğitimi arasında mevcut veya olası ilişkiler üzerine çalışmalar yapılmaktadır (Doğan \& Şener; 2014; Yorulmaz, 2013a; Yorulmaz, 2016). Bu tür yeni yol arayışları ve aktüel duruma uyum sağlama çabaları, medya okuryazarlı̆̆ eğitiminde olduğu gibi, uzun bir zamandan beri eğitimcilerin ve toplumların (özellikle de Batı toplumlarının) gündemini işgal etmektedir. Enformasyon süreçlerinin dışına taşarak hemen her şeye ulaşmada (ya da hemen her şeyin bireye ulaşmasında) bir araç haline gelmesi, dikkatleri kitle iletişim araçlarının üzerine çekmiş görünmektedir. Anne babaların çalışma zorunluluğu, akran ilişkileri, anne babanın otoritesinin yerini önce öğretmene, daha sonra da ergenlikte yaşanan rol karmaşası nedeniyle bireyin kendini özdeşleştirebileceği bir rol modele bırakması, gittikçe artan bir ivmeyle bireyi dış etkilere açık hale getirmektedir (Vrabec, 2013, s. 211-223). Diğer taraftan rekabetin olanca saldırganlığıyla yaşandığı devletlerin ilerleme mücadelesi, hayat boyu öğrenme gibi yeni eğitim yaklaşımlarının ortaya çıkmasına neden olmuştur. Dolayısıyla, eğitim potansiyelini içinde barındıran her araçtan maksimum seviyede yararlanma yoluna gidilmesi bir zorunluluk olarak görülmektedir.

Eğitimde yaşanan bu gelişmelerden ayrı olarak tüketim araçları ve alışkanlıklarında da radikal değişimler gözlemlenmektedir. Özellikle orta sınıfın bir toplumsal kategori olarak yükselişi, yeni bir pazar anlayışını da beraberinde 
getirmiştir. Televizyonun her eve girmesi, internetin kişisel bilgisayarlar ve cep telefonları vasıtasıyla bireysel kullanımının yaygınlaşması, yeni tüketim alışkanlıklarına aracılık etmektedir. Her yerde simülakrlar karşımıza çıkmakta ve bizi bir şeylere davet etmektedirler. Düzenin devam edebilmesi için herkes 'bilgilendirilmeli', yeni olan her şeyden haberdar edilmelidir. Bu nedenle reklam, merkezi bir rol üstlenmektedir.

Makro düzeydeki söz konusu durum, sinemanın bir eğitim aracı olarak kullanımını kuşkulu kılmaktadır (Walters, 2012, s. 39). Özellikle de hayatın bütününe yönelen ve hayatı daha yüksek bir amaç için koşul kılan İslam dininin amaçlarına gönüllülükle hizmet etmesi, pek olası görünmemektedir. İmgelerin ve seslerin, belli bir hesaplamaya ve kusurlardan arındırmaya dayalı bir şekilde örgütlenmesi ile görme ve işitmeye dayalı bir hakikatin kendisini açması arasındaki ilişkiyi kuşkulu kılan, sinemanın doğal bir göstergeler toplamı mı yoksa bir simülakr mı olduğuyla ilişkilidir. Bilindiği gibi peygamberlerde görme ve işitme, hakikatin açıklanması sürecinde eşzamanlı olarak vuku bulmaktadır. Üstelik peygamberler dahi, ancak ve sadece bir 'örnek' olabilmektedirler. Diğer taraftan onlar, bir göstergeden çok daha öte olmak zorundadırlar zira onların yaptığı bir rol değildir. Hakikatin kaynağıyla daimî bir ilişki içerisindedirler. Varlıkları, kişiliklerinin bir parçası haline gelmiş ilke ve değerler manzumesini yansıtmaktadır. Başka bir deyişle hakikat onların fiillerinde türetilmemekte aksine hakikat, fiillerini ortaya çıkarmaktadır.

Hakikatin işitilmesi ve görülmesi, gayri sahih anlam dünyasında bir farkl1l1k olarak görülmektedir. Hakikatin işitilmesi, anlamın gelişi güzel bir sentaks ve semantikten türetilmediğini, aksine antropolojik olana önsel olduğuna işaret etmektedir ki Kuran-1 Kerim'de antropolojik olanın yerildiği görülmektedir (Altıntaş, 2005, s. 101 vd). İnsanın hakikate sahip olamadığı gibi, hakikatle hakikat olmayan arasında -doğası gereği- salınımda bulunması, aracın kullanımının sadece nesne üzerinde değil, fail üzerinde de etkisinin olduğuna işaret etmektedir. Diğer taraftan hem Kur'an-1 Kerim'de hem de diğer kutsal kitaplarda mucizelerin genellikle görme duyusu ile ilgili olduğu görülmektedir (Kur'an-1 Kerim, 2/66; 6/6; 41/15; 91/13-14; Yaratılış 8; Çıkış 14; Markos 4: 37-9 ). Görme, hakikatin kendisini anlamla birlikte ama farklı bir tarzda tezahürünü temaşa etmek anlamına gelmektedir. Sahih/derin bir görmede, görme ile anlamın birlikteliği, theoria kelimesinde olduğu gibi kendini göstermektedir. Bu sözcüğün, sözlük anlamı 'seyretmek, temaşa etmek' iken, terim olarak soyut ve derin düşünmeye karşıllk gelmektedir (Peters, 2004, s. 374). Sinemada da kulak ve göz, 
yapay gerçekliğe uygun olarak koşullanmakta gibidir. Sinema filminden ibret alınmasını engelleyen, sadece yapay gerçeklik ya da gerçekliğin yapay sunumu değildir; yukarıda değinildiği gibi, simülasyon evreninde asimetrik bir yapı bulunmaktadır. Görme ve işitme, bütünüyle hayatın pozitif yönüne odaklanmış haldedir. Oysa hayat, bir negatife de sahiptir.

Pazarlık, (yani belli alışkanlıklar karşılığında belli alışkanlıklar, belli değerler karşılığında belli değerler) kesinlikle simülasyonun kazançlı çıkacağı anlamına gelmektedir. Şeyleri meta haline getirmedeki başarısı ve kendi kurduğu düzende uygulamaların yürürlüğe girecek olması, zaten avantajın kimde olduğunu aşikâr kılmaktadır. Baudrillard'ın düşüncelerine göre sinema, diğer bütün simülasyon modellerinde olduğu gibi, simülasyon evreni adına vekalet savaşı yürütmektedir (Kellner, 2009, s. 98-101). Hal böyle iken sinemanın, metafizik boyutu olan farklı bir evreninin kendi içinde reklamını yapması, simülasyon mantığına ters düşmektedir. Dahası, kutsal bir olay veya kişiyi, sinemanın yeniden canlandırma imkânı bulunmamaktadır. Ekrana yansıyan imgelerin kurduğu köprü üzerinden öbür dünyayı anlayabilmek ya da bir töze, ilkeye, değere ilişkin kolektif bir şuura ulaşmak, simülakrın ne yapabileceği ne de razı olacağı bir durumdur. Zira ekran, geleneksel temsilde var olan sahne ve izleyici arasındaki eşitlikçi bağı koparmıştır ve ekranın propagandasından bir irade beklentisi muhaldir (Baudrillard, 2005c, s. 77). Göstergenin, anlamı karş1 ekrana (göze) aktarabilmesi için, öncelikle bir göndergesinin var olması gerekir ve bu gönderge, kendi anlamını kendisi açığa vurmalıdır. Dahası bu anlam hakkında, izleyici daha önceden öyle veya böyle bir fikre, bir hazırbulunuşluluğa sahip olmalıdır (Baudrillard, 2005c, s. 91). Ne var ki sinema, hakikate sadik davranmamakta; onun simgeselliğine manipülasyonla/cerrahi bir müdahaleyle son vermekte, işaretlerin aşkınlığa açılan kapılarını geriye hiçbir iz kalmayana dek kapatıp işlemekte ve integral ve sanal bir görüntüye dönüştürmektedir. Sinemada sunulan imgeye yönelen zihnin, imge üzerinden anlama ulaşabileceği diyalektik bir süreç hiç yaşanmamaktadır. Yönelim, hiçliğin yüzeyini kapsayan imge üzerinden çeşitli yönlere yansitılmakta; süreç, sürekli olarak imgeler üzerinden başka imgelere doğru devam edip gitmektedir. Ne tür bir imge/gösterge olursa olsun, o asla antitez görevini görmeyen, diğer yanı nihilizm tarafından kusursuz bir şekilde parlatılan bir aynayı andırmaktadır. Hâlbuki geleneksel düşüncede imge/ gösterge, daha derinde yatan hakikati açığa çıkarmaktadır. Bakışı yutmak bir tarafa, metafizik/onto-teolojik bir âleme yansitmaktadır (Güler, 2004, s. 103121). Geleceğe yazgılı k1lıp 'şimdi’ ve 'burada'ya hapsetmek yerine, kozmik 
bir zaman (zaman üstü bir zaman) ve kozmik bir mekânda (mekân üstü bir mekân) seyir makamına yükseltmektedir. ${ }^{9}$ Gösterge, aşkın olanın tecellisine ev sahipliği yapmaktadır. Bu süreçte hem insan hem imge hem de metafizik varlık, hürmete sahiptir. Göndergeden yoksun göstergelerden inşa edilen sanal evren, sadece gerçek dünyanın değil, hem bir adım gerisinde hem de bir adım ilerisinde (her ikisiyle de aynı anda) konumlanmış olan metafizik dünyanın da yerini almıştır. Gerçek dünyanın her türlü kusursuzluklardan arındırılmışs şekli olan integral gerçeklik, hem maddi dünyanın hem de öteki dünyanın yerini almıştır ve bilinçdışının bu mükemmel yansımasını aşacak araç bulmak imkânsız hale gelmiştir (Baudrillard, 1991, s. 25). Diğer taraftan simülakrda, "dilsel boşluklar ve sessizlik anlarıla birlikte, negatif film şeridinin sentetik imge tarafindan saf dışı edilmesine benzer şekilde edebi nitelikler de yok edilmektedir. Bu yalnızca dile özgü bir ayarlama sürecine karşı koyan bir şeyin saf dışı edilmesi olarak da görülebilir: bütünsel (integral) gerçeklik” (Baudrillard, 2005c, s. 27). Gösterge ve göndergesi arasında var olması gereken bağın kopartıldığı, kategorilerinin anlamdan yoksun olduğu göstergelerin gelişigüzel/ilkesiz (ama yine de bir hesapla) eşleştiği bu yapaylıkta, muhakemenin arasına yerleşebileceği ve nedensellik bağıntısının kurulabileceği bir mesafe bulunmamaktadır (Baudrillard, 2010b, s. 29). Ekranın görüş açısına girmesiyle birlikte birey, dijital görüntünün içerisinde konumlanmaktadır. Baudrillard'ın deyimiyle "ekranın içerisine yaşamın içine girercesine dalmaktayız" (Baudrillard, 2005c, s. 75). En ufak bir derinliği bile olmayan ekrana dalmaktayız çünkü ekran bizi kendine çekmektedir; ürettiği titreşim zihnimizle çakışmaktır. Simülasyon düzeninin büyüleyiciliği, rezonanstaki başarısında yatmaktadır. Neil Postman'ın ifade ettiği gibi "ekranın dindarlık, fazilet ve güzellik kavramlarımızı etkileyebilecek gücü bile olur” (Postman, 1994, s. 27). En özgür ve eleştirel bir zihin bile, za-

\footnotetext{
9 Zaman, deneyime bağlı olarak bölündüğünde doğası/niteliği değişmekte ve gösterge sisteminin bağımsız çokluğuna koşut bir şekilde, sonsuzluk ve sonsuzluktan devşirilen an arasındaki bir kavrayıştan, birliğini kaybetmiş bir somutluğa dönüşmektedir. Bu, "doğası dönüşerek bölünen"den geriye kalan işlemdir. Deleuze'ün farklı bir bağlamda da olsa vurguladığı gibi zaman ile benlik arasında yapısal bir ilişki bulunmaktadır. O, şöyle demektedir: "Zaman Ben'de bir fay ve veya bir çatlak, benlikte de bir edilginlik anlamına gelir...” (Deleuze, G. (2017). Fark ve Tekrar. çev. Burcu Yalım, Emre Koyuncu, İstanbul: Norgunk Yayınları, s. 126). İnsan, bu kırılmanın iki tarafindaki eşit olmayan parçaları arasındaki ilişki ile dünya-içinde-olmaktadır. Bu açıklamayı, bir metafora çevrildiğimizde, onun zamanın gösterge sistemleri içinde dağlımının benliğin anlamlandırma süreçlerini en üst sınırlarına kadar zorlayacağı görülür. Zira zaman ya da zaman deneyimi, ister tümel temsiller olarak kabul edilsin isterse de sonsuz küçüklerin bireysel ardışıklı̆̆nın zihinde işlenmesi olarak yorumlansın, Ben ile benliği birbirine bağladığı için benliğe birliğini veren ilke ya da zemin olacaktır. Belki de geleneksel toplumda arzu ile thanatosu birbirinden ayıran ince sınır, zamanın bu aşkınlı̆̆ılır. Sinema gibi modern araçların zamana karşı amansız saldırısının altında da muhtemelen bu durum yatmaktadır. Zira zamanın sınırsız parçalanması, benliğin de Ben'in kuşatamayacağı bir 'çokluk'ta benliğini kaybetmesi demektedir. Zamanın ontolojik ve epistemolojik tahlili için bkz. Kant. (2015). Arı Usun Eleştirisi. çev. Aziz Yardımlı, İstanbul: İdea Yayınları).
} 
man ve mekân tarafından kuşatılmış olduğundan ve en muhkem fikirler dahi bilinçdışı gibi nankör ve akışkan bir zemin üzerinde temellendiğinden, hiçbir yasaya uymayan, yörüngesi olmayan, fraktal yapısından dolayı sonsuzca çoğalabilen simülasyon karşısında acizdir. Karşılıklı rızaya dayanmayan ilişkilerde tamamıyla kendi yararına kendi çekim gücüne eklemleyebilen, zihnimizi şekillendiren kategorileri eğip bükebilen simülakr -çoğu zaman zamanın nasıl geçtiğinin farkına varamayız ya da reklamlardaki bütün anlam kategorilerine meydan okuyan ve aslında çocukça olan sihirvari görüntüleri yadırgamaz hatta kalite algımıza etki etmesine izin veririz- rızanın var olduğu bir ortamda her türlü edime, gönüllü bir köle bulmanın mutluluğu ile yaklaşacaktır. Gönüllülüğün olmadığı durumlardan kasıt ise, algı eşiğimizin dışında yer alan sesler veya hızlı akan görüntüler nedeniyle mantığımızın çevresini kurnazca dolaşan etkilerin, bilincimizi hedef almasıdır. Özgürlük ve irade kavramına en düşmanca müdahalelerden birini oluşturan bu tür uygulamalar, bilindiği gibi çizgi filmlerden, alışveriş merkezlerine kadar pek çok alanda yürürlüktedir.

Görüntüde yansıyan söz konusu integral gerçeklikle, müzikte de karşıllaş11maktadır. Bilgisayarlar tarafından bestelenen müziklerde, gerçekliğe delalet eden kusurlar bertaraf edilmekte, parazitlerden soyutlanmakta, sahte olduğunun en büyük delili olan mükemmelleştirilmeye tabi tutulmaktadır. Böylelikle müzik, sayıların egemenliği altında ve yine sayılara indirgenerek yapay bir ses dalgasına dönüştürülerek arz edilmektedir (Baudrillard, 2005c, s. 25). Hatta bireysel ya da kolektif bütün irade çağrılarına ekran duyarsızlaşma, uyuşukluk ve eyleme arzusundan yoksunlukla karşıllık vermektedir. Toplumu kitleselleştiren simülasyon, tekrar toplum haline getirme çabalarına olumlu katkıda bulanamaz. Baudrillard simülakrın bireye yönelmesinin koşullarını şu şekilde açıklar:

"Makineler yalnızca makine üretir. Bilgisayarda üretilen metinler, imgeler, filmler, söylevler, programlar mekanik bir üretim sonucu olup, bu üretimin özelliklerini taşımaktadırlar. Ne pahasına olursa olsun çalışmak, iş görmek isteyen bu kurnaz makinelerde (bu onlara özgü bir tutku gibidir) üretilen her şey yapay boşluklarla birbirinden ayrılmakta, hataları düzeltilmekte, filmler özel efektlerle doldurulmakta, metinler istenildiği kadar uzatılıp, yinelenebilmektedir. Kullanıcı da bu sınırsız işleve sahip araç tarafindan büyülenmektedir" (Baudrillard, 2005c, s. 80).

Dini içerikli filmlerin aşamadığı engel de budur: gösterge, aşkınlıkla olan bağ kopartılıp yüzeye dönüştürüldüğünde ve onları metafiziksel dünyaya bağlayan kökleri söküldüğünde, düşselliğini kaybetmekte ve artık çekilmez olmaktadırlar. Katıksız bir integral gerçeğe dönüşen gösterge, amacıyla ters düşmektedir 
(Baudrillard, 2005c, s. 25). En etkileyici oldukları an, fantazma oldukları andır. Baştan çıkarma, yüzeyde gerçekleşmektedir. Söylem hakikatin derinliğine yöneldiğinde, onu kullandığında, geçersiz kılmakta ve yerine imgelerin cazibesini ve tuzağını koymaktadır. Kurgu, söylem ve imge baştan çıktığında, eş güdümlü olarak izleyiciyi de baştan çıkardığında, anlamı gösterge uğruna kurban ettiğinde, dil de aynı şekilde baştan çıkmaktadır (Baudrillard, 2005a, s.70). Anlatılan bir kıssadan kimseye en ufak bir hisse bile düşmemektedir. Cümleler dahi gerçek anlamda yargı bildirememektedirler. Üstelik ilerleme nosyonu ve rekabet ortamı, bunu yapmaya istekli ortakların sürekli hazır ve nazır olmalarını kolaylaştırmaktadır. Birey ve gösterge arasını dolduran bütün iletişim ve enformasyon araçlarının olduğu gibi sinemanın da görevi, kusursuz yansımanın sürekliliğini sağlayacak yeni göstergeler üretmektir. Sayıların projeksiyonunda kesilip biçilen sahneler, uzam algımızın sınırlarını aşan açılar, nesneye her yönden gelen 1şıkların eritip buharlaştırdığı gölgeler, zoomlar, filme gömülmüş olan müzik, gerçeği müstehcenleştirmektedir. Gerçek hayatta olmayacak derecede imgeye itilmemiz, müstehcenleştirmeyi artıran bir diğer faktördür. Zaten gerçeğin yapaylaştırılması, başlı başına bir müstehcenleştirmedir. Baudrillard'ın ifadesiyle:

"Her türlü gerçek olasıllı̆ııı kusursuz bir duplikasyonla caydırma, makroskopik bir aşırı sadakat, hızlandırılmış bir yeniden yönlendirme, doyurma, gerçekle ve gerçeğin canlandırılması arasındaki uçurumun kapanması sonucunda, gerçeğin enerjisinin içinden geçtiği ayrık kutupların içten patlamasıyla caydıran bu hipergerçeklik, hem sistem hem de gönderen olarak ortadan kaldırıp model düzeyine yükselttiği gerçeği yok etmektedir” (Baudrillard, 2008, s. 58).

İmgeleri kusursuzlaştırma müdahaleleri -güzelden güzel, gerçekten daha gerçek kılma- imgeyi kendi kendini aşmaya mahkûm etmek anlamına gelmektedir. Sinemada, tutkunun ortaya çıkması ve imgelere tutkuyla bağlanabilmemiz için zıtlıklar törpülenmektedir (Baudrillard, 2002, s. 54). Karşıtlıkların yerlerinden edilmesiyle doğru-yanlış, iyi-kötü, güzel-çirkin gibi kavramları ve bunlarla nitelendirilebilecek olgu ve olayları aktarmak da zorlaşmaktadır. Bu dairesel bir harekettir, "zira aşılıp geçilen bu özellikler, olumlu anlamda yüceltilmiş ve dolayısıyla karşıtlarının anlamlarını kendi hesaplarına geçirmiş olmaktadır" (Baudrillard, 2011, s. 9-10). Hatta her kavram çifti, imgeye içkin kılınmaktadır.

Simülakr tecrübesinde/sinemada yaşanan rezonans halini Baudrillard 'orji sonrası hal' olarak ifade etmektedir. Orji ${ }^{10}$, tüm savunma mekanizmalarını, tüm

10Yunanca orginon, mistik inançlarda özellikle Dionysos ve Kibele adına yapılan ayine verilen isimdir. Erkeklerden daha çok kadınların rol aldığı bu ayinlerde hayvan kanı içildikten sonra, esrime (extacy) halinde toplu cinsel ilişkiler yaşanmaktadır. 
toplumsal yasaları, metafizikle bağlantılı tüm tabuları yıkarak 'özgürlüklerin' patlamasıdır. Karşı kutupların içe çökmesiyle, sinemanın vaat edebileceği en üst nokta böyle bir esrime halidir. İzleyicinin karşıya, sahnenin diğer tarafina değil, ekranın içerisine yerleşmesi, duygu boşalmaları buna işaret etmektedir (Baudrillard, 2010a, s. 9). Bu, bireyin kendinden geçmesi, sinemanın bireyi ayartmasıdır. Din eğitimi için böyle bir aracın kullanımı, kendi kendini yok etmek anlamına gelecektir. Dostoyevski'nin veciz bir şekilde belirttiği gibi, en başta imanın en saf hali, iradenin en saf olmasıyla ortaya çıkacaktır. Tutkuların esiri olmuş bir insan, kendinden geçmiş kitleler, hakikati tecrübe etmek için gerekli olan dinginliği hafife alacaklardır (Dostoyevski, 2014, s. 328 vd).

Rol modellerle özdeşleşme bir diğer sorunu oluşturmaktadır. Model, doğası gereği bütün rol algılarını aşarak ön plana yerleşmektedir. Starlar, karanlıkta bir an parlayıp yoklukta kaybolan flaşlar gibidir; 1şıkları süreklilik göstermez, çevreyi anlatmaz ve herhangi bir yola da işaret etmezler (Baudrillard, 2005a, s. 119). Durumları daha çok, bir kavşakta olduğu yerde sürekli dönüp duran yön levhaları gibidir. Dini bir imgede bile, izleyenleri manipüle edip niyetlerini kötüye kullanma ihtimali her daim mevcuttur. 'İdol' olmaları demek, bir göndergeyle olan bağını koparıp ilgileri bütünüyle kendinde toplamaları demektir. Onlar, zenginlik değil zenginlik göstergeleri üreten politik iktisat gibi, sadece simülakra içkin olan takas edilemeyen değere, olay olmayan olaya, tabii ki pazarlanmasi/kâr getirmesi amacıyla üretmeye güdülenmişlerdir (Baudrillard, 2005b, s. 138). Anlam transferi için bir araç olan idol, zamanla anlamın yerini alabilir çünkü ancak bu şekilde varlığını devam ettirebileceğini çok geçmeden anlayacaktır. İlkesel olarak, imlemeye çalıştıkları kutsallıkla aralarında aşamayacakları kategorik bir ayrım bulunmaktadır. Sinema starı, iradeyi aşarak büyülemek amacındayken kutsallık, iradeyi tahkim edip bir taraftan öbür dünyayla/kozmik zaman ve mekânla bağ kurmaya çalışırken diğer taraftan sorumluluk yükler. Starın aktör/aktris olması gerekir; yüzü/yüzeyi, kendi ruhunun bir yansıması, duygulanımlarının tezahürü değildir, '-mış gibi yaparak' hakikatin varlığını değil yokluğunu gizlemeye çalışmaktadır. Bu gizlemeyi yapabildiği ölçüde başarılı olmaktadır. Hakikati, jest ve mimiklerinin, haddinden fazla zoomlanan gözbebeklerinin, kostümlerin, üzüntü ve sevinçlerinin değersizliğinde yapaylaştırması gerekmektedir (Baudrillard, 2005a, s. 118.). Trajik bir biçimde, filmin sonunda alkışlar, bravolar ve diğer beğeni bildiren davranışlar eşliğinde bir sonraki projede yeniden doğmak üzere öldürülmekte; ekranın karanlığına, hiçliğin dipsiz kuyusuna mahkûm edilmektedir. Diğer taraftan, sinematerapi gibi sinema, psikoloji ve değerin iç içe geçtiği yeni taktiksel edimler, seküler 
bir rasyonaliteyi benliğin içine yerleştirmektedir. Konuyu ele alan çalışmaların da ifade ettikleri gibi, insanın bireysel ve toplumsal sorunları ile inşa edilmiş bir dil oyunu arasında kurulan ilişki, zihnin işleyişine dâhil edilmektedir. Başka bir deyişle atanan ve düzenlenen metaforlar, bir tür ilaç gibi kullanılmaktadır zira "metaforlar benliğin, hayatın ve ötekilerin içsel imgelerini yansitırlar ve bu yolla kişilerin kendilerini daha açık bir şekilde ifade etmelerine yardımcı olan birer katalizör vazifesi görür" (Coşkun, 2015, s. 183). Burada tuhaf olan, dili dönüştüren ve imgeyle aktarılan, kişiye dışsal bir bağlamın zihnin mantıksal işleyişini teğet geçerek -ki zihnin topoğrafik sınıflandırmasının bütünlüğün kaybedilmesine sebep olmasının sonuçları, Freud'un sınıflandırmasına yönelik eleştirilerden beri bilinmektedir- yaratıcı bölümü hedeflemesinin yine kişi tarafından sanki kendi fiili gibi görülmesidir.

Kutsalla ilişkili kişilerin ve olayların yeniden canlandırılması başka açılardan da zorluklarla karşı karşıyadır. İlerleme düşüncesinin karakteristik olduğu bir sistemde, 'şimdi' sürekli olarak 'dünden'; 'gelecek' de 'şimdiden' daha yüksek bir mükemmellik düzeyinde konumlanacaktır. Geçmiş̧e özlem, geçmişe dönme arzu ve çabaları veya geçmişten özsel bir biçimde ders alma ve onu rehber tayin etme, simülasyon tarafından radikalleştirilecektir. Diğer taraftan dünün ve bugünün sentezine ulaşmaya çalışmakta da farklı bir sıkıntı ile karşılaşılabilmektedir: her daim diğerinin yerini alma tehlikesinin bulunmasının beraberinde getirdiği meşruiyet krizi bunun en önemlilerindendir. Gelenek ve modernite arasında trajik bir kimliği taşımaya mecbur görünen, gelenek ve modernitenin aynı anda biçimlendirdiği toplumların bireyleri için simülakrlar, trajedinin daha fazla derinleşmesi yönünde işlevsel olacaktır. Dini ya da geleneksel bir temanın, bir simülakr aracılığıyla sunumu, simülakrla ilgili olması hasebiyle bilinçdışıyı ya da arzuyu edimselleştirdiği gibi, temanın içeriği de bilinçte bir uyarılmayı gerçekleştirecektir. Her bir tekrarda trajedi, daha fazla büyüyecektir. Bu durum ise, simülakrın bir sonraki seferde daha fazla etki edebileceği bir alan açacaktır. Daha önce zikredildiği gibi, akla dair aşırı vurgunun aksine, simülasyonun duygular yoluyla kendi gerçekliğini oluşturmuş olması, trajediyi tamamlayan diğer olumsuz kutbu teşkil etmektedir. Yani, simülakrın dindarlığın oluşmasına ya da güçlenmesine katkıda bulunduğu kabul edilecek olsa bile bu, kökleri bilinçd1şında bulunan duygular üzerinde gerçekleşmiş olacaktır. Tıpk1 varsayımsal bir iradenin varlığında olduğu gibi, dindarlık da kişiliği inşa edebilecek bir potansiyelden uzak kalacak, bilişsel ve davranışsal imkânları mümkün en alt seviyede tutmaya çalışacağından -zira bilgi ile bütünleşmiş bir davranış, gerçek anlamda ahlaki bir davranış olacaktır- belki de bir yanılsamadan ibaret olacaktır. 
Anlamlandırmanın ilkesinin ‘bugün' olması, kutsala saygısızlık olarak görülebilir. Bundan başka, kusursuz bir hikâyenin kusurlu gerçek hayatta izdüşümünün olmaması sebebiyle, örnekliği gerçekçi olmayacaktır. Birey, kusursuzluktan anlık olarak etkilense dahi, er veya geç zıtlığı fark edecektir. Mütekabiliyeti olmayan kategoriler üzerinden anlam transferi mümkün olmayacaktır. Çağlar üstü özelliğini haiz bir din için, gerçekte içselleştirilmemiş bir hakikatin perspektife bağımlı bir somutlaştırması, her halükarda sorunlu olmaktadır.

\section{Sonuç}

Simülasyon evrenin ve simülakrların işlevlerinin en önemli kanıtlarından ve aynı zamanda sinemanın bir din eğitimi öğretim aracı olarak kullanılmasının problemli olacağının en belirgin işaretlerinden birisi, her türlü bireysel-işbirlikli aktivitelerle, tikel-tümel yaklaşımlarla ya da yasalar-ahlaki normlarla girişilen bütün iyileştirme faaliyetlerinin hüsranla neticelenmesidir. Zararlı alışkanlıkların ve suçların hiperbolik artışı bunu net bir biçimde göstermektedir. Şüphesiz ki, Baudrillard'ın düşünce sisteminin de eksik ya da hatalı yanları olabilir. Fakat sinemanın bir öğretim aracı olarak kullanımına artan ilgiyi dengeleyecek bazı uyarıların olması gereklidir ve Baudrillard'ın bunu içerden gerçekleştirmesi hayati bir önem taşımaktadır. İzleyici kitlesinin sürekli olarak büyümesi, empati ve sempatiyi aktarması bir avantaj olarak görülebilir fakat en azından yan etkilerinin de hesaba katılması gerekmektedir.

Genel okuyucu için Baudrillard'ın düşünceleri, sağduyunun kabul edebileceğinin ötesinde ve aşırı görülebilir. İçinde yaşadığımız dünyanın, bir simülasyon olduğuna inanmak ve varoluşumuzun simülakrların bir üretimi olarak görmek, muhakkak ki kolay olmayacak bir edimdir. Zira ikna edilmiş bir yanılmanın dışındaki 'gerçek' dünyanın tasavvuru, oldukça zordur. Ne var ki, Batı uygarlığına yönelik şiddeti ve içeriği zamana göre değişen eleştiriler de, söz konusu bu uygarlığın ontik farklılığına işaret etmektedir. Sinemanın bir öğretim aracı olarak din eğitimi uygulamalarında kendine yer bulması, bu açıdan paradoksal bir görünüm arz etmektedir. Salt fayda-zarar ilkesinden hareketle, ontolojik değerlendirilmesi yapılmamış bir tekniği kullanmak, dinin kendi özüyle uyuşmayacak sonuçlar doğurmasına sebep olacaktır. Bu açıdan onun düşünceleri, din eğitimi uygulamalarında işe koşulan tekniklerin en azından risklerini gözetmenin gereğini ortaya koymaktadır. 


\section{Kaynakça}

Altıntaş, R. (2005). Din ve sekülerleşme. İstanbul: Pınar Yayınları.

Altun, F. (2006). “M. McLuhan ve J. Baudrillard'ın medya kuramlarının karşılaştırmalı çözümlemesi” (Yayımlanmamış doktora tezi). İstanbul Üniversitesi SBE, İstanbul.

Baudrillard, J. (1991). Sessiz yığınların gölgesinde ya da toplumsalın sonu (O. Adanır, Çev.). İstanbul: Ayrıntı Yayınları.

Baudrillard, J. (2002). Tam ekran (B. Gülmez, Çev.). İstanbul: YKY.

Baudrillard, J. (2005a). Baştan çıkarma üzerine (A. Sönmezay, Çev.). İstanbul: Ayrıntı Yayınları.

Baudrillard, J. (2005b). Imkânsız takas (A. Sönmezay, Çev.). İstanbul: Ayrıntı Yayınları.

Baudrillard, J. (2005c). Şeytana satılan ruh (O. Adanır, Çev.). Ankara: Doğu Batı Yayınları.

Baudrillard, J. (2006). Kusursuz cinayet (N. Sevil, Çev.). İstanbul: Ayrıntı Yayınları.

Baudrillard, J. (2008). Simgesel değiş tokuş ve ölüm (O. Adanır, Çev.). İstanbul: Boğaziçi Üniversitesi Yayınevi.

Baudrillard, J. (2009). Gösterge ekonomi politiği hakkında bir eleştiri (O. Adanır ve A. Bilgin, Çev.). İstanbul: Boğaziçi Üniversitesi Yayınevi.

Baudrillard, J. (2010a). Kötülüğün şeffaflı̆̆l: aşırı fenomenler üzerine bir deneme (I. Ergüden, Çev.). İstanbul: Ayrıntı Yayınları.

Baudrillard, J. (2010b). Sanat komplosu (E. Gen ve I. Ergüden, Çev.). İstanbul: İletişim Yayınları.

Baudrillard, J. (2011). Çaresiz stratejiler (O. Adanır, Çev.). İstanbul: Boğaziçi Üniversitesi Yayınevi.

Baudrillard, J. (2014). Simülasyon ve simülakrlar (O. Adanır, Çev.). Ankara: Doğu Batı Yayınları.

Bayrı, D. (2011). Gözün egemenliği tarihin sonu mu?. Özne Dergisi, 14, 93-104.

Benjamin, W. (2015). Fotoğrafin kısa tarihi: teknik araçlarla yeniden üretim çă̆ında sanat eseri (G. Sarı, Çev.). İstanbul: Zeplin Yayınları.

Betül O. D. \& Şener, N. K. (2014). Medya ve din. İstanbul: Köprü Kitapları.

Bogard, W. (1990). Closing down the social: Baudrillard's challenge to contemporary sociology. Journal of Social Theory, 8(1), 1-15.

Borges, J. L. (1993). Alçaklığın evrensel tarihi (Z. Çağlayan, Çev.). İstanbul: Telos Yayıncilık. 
Coşkun, M. K. (2015). Değerler eğitiminde sinematerapinin imkânı ve gücü. Bilal Yorulmaz ve diğerleri (Ed.). Sinema ve Din içinde (s. 175-192). İstanbul: DEM Yayınları.

Coşkun S., Saraçlı, S. (2015). Dini içerikli filmlerle karşı tutum ve davranışların din eğitimi bağlamında istatiksel tekniklerle incelenmesi: AKÜ İslami İlimler Fakültesi öğrencileri üzerine bir uygulama. Bilal Yorulmaz ve diğerleri (Ed.). Sinema ve Din içinde (s. 109-129). İstanbul: DEM Yayınları.

Deleuze, G. (2015). Anlamın mantığı (H. Yücefer, Çev.). İstanbul: Norgunk Yayinc1lik.

Deleuze, G. (2017). Fark ve tekrar (B. Yalım ve E. Koyuncu, Çev.). İstanbul: Norgunk Yayınları.

Doğan, B. O., Şener N. K. (2014). Medya ve din. İstanbul: Köprü Kitapları.

Dostoyevski, F. M. (2014). Karamazov kardeşler (N. Yalaza Taluy, Çev.). İstanbul: İş Bankası Kültür Yayınları.

Gane, M. (1991). Baudrillard's bestiary: Baudrillard and culture. London: Routledge

Güler, Z. (2004). Şeyh Galib divanında ayna sembolü. Fırat Üniversitesi Sosyal Bilimler Dergisi, 14(1), 103-121.

Güzel, M. (2015). Gerçeklik ilkesinin yitimi: Baudrillard'ın simülasyon teorisinin temel kavramlar1. FLSF, 19, 65-84.

Kellner, D. (2009). "Baudrillard and the art conspiracy". Jean Baudrillard: Fatal Theories içinde, David B. Clarke, Marcus A. Doel, William Merrin, Richard G. Smith (Ed.). London: Routledge.

Kellner, D. (1989). Jean Baudrillard: From marxism to postmodernism and beyond. Standford: Standford University Press.

Koch, A. M \& Elmore, R. (2006). "Simulation and symbolic exchange: Jean Baudrillard's augmentation of Marx's theory of value". Journal of Politics \&Policy, 34(3), 556-575.

Korkmaz, M. (2015). Din dersi öğretmenlerinin bir öğretim materyali olarak filmlerden yararlanma durumu. Bilal Yorulmaz ve diğerleri (Ed.), Sinema ve Din içinde (s. 85-107). İstanbul, Türkiye.

Korukçu, A., Güngör, M., Ardahanlı, Ö. (2015). Animasyon filmlerin değerler bağlamında değerlendirilmesi. Bilal Yorulmaz ve diğerleri (Ed.), Sinema ve Din içinde. (s. 53-83) İstanbul: DEM Yayınları.

Kur’ân-1 Kerim Meâli. (2017). Ankara: Diyanet İşleri Başkanlığı.

Kutsal Kitap (Tevrat, Zebur, İncil). (2010). İstanbul: Yeni Hayat Yayınları.

Lane, R. J. (2001). Jean Baudrillard. London: Routledge. 
McLuhan, M. (2013). Understanding media: The extensions of man. Berkeley: Ginko Press.

Pawlett, W. (2007). Jean Baudrillard: Against banality. London: Routledge.

Peters, F. E. (2004). Antik Yunan felsefesi terimleri sözlüğü (H. Hünler, Çev.). İstanbul: Paradigma Yayıncılık.

Postman, N. (1994). Televizyon öldüren eğlence (O. Akınhay, Çev.). İstanbul: Ayrintı Yayınları.

Postman, N. (1995). Çocukluğun yok oluşu (K. İnal, Çev.). İstanbul: İmge Yayınları.

Schumpeter, J. A. (1950). Capitalism, socialism and democracy. New York: Harper and Brothers Publishers.

Turan, M. (2007). Nihilizm ve Jean. EÜHFD, 11(1-2), 87-103.

Vrabec, N. \& Polievková, P. \& Moravčíková M. (2013). The role of media literacy development as a part of religious education curriculum. European Journal of Science and Theology, 9(5), 211-223.

Walters, J. (2012). Baudrillard and theology. London \& New York: T\&T Clark International.

Yorulmaz, B. (2013a). Filmlerle din kültürü ve ahlak bilgisi dersi. Ankara: Nobel Yayın Dağıtım.

Yorulmaz, B. (2013b). Pepee çizgi filminin din ve değerler eğitimi açısından değerlendirilmesi. Uluslararası Sosyal Araştırmalar Dergisi, 24(6), 438-448.

Yorulmaz, B. ve Tanrıverdi Z. K. (2015). Din ve değerler eğitimi açısından keloğlan çizgi filminin değerlendirilmesi. Bilal Yorulmaz ve diğerleri (Ed.), Sinema ve Din içinde (s. 29-53). İstanbul: DEM Yayınları.

Yorulmaz, B. (2016). Sinema ve din eğitimi. İstanbul: DEM Yayınları. 


\section{The Possibility of Using Cinema as a Media Tool in Religious Education: An Evaluation in The Context of Baudrillard's Theory of Simulation}

Süleyman GÜMÜŞ, Corresponding Author, Dr.

E-Mail: suleymangumus@yahoo.com.

ORCID: 0000-0003-2202-5121

\section{Introduction}

The growing role of the media in everyday life brings with it debates on its positive and negative aspects, or on its possibilities and limitations. The fact that having wide effect of media on almost all arenas, or in other words its success in the intermediary role, makes it hard to make a definite decision about it. So, in addition to those who think that media tools needs to be utilized in religious education as well as in other fields because of its success, there are also those who have the view that the media tools are very modern product of modernity and not appropriate to use in many fields. For example, Neil Postman, author of Amusing Ourselves to Death, The Disappearance of Childhood, claims that media tools are far more capable function than information transfer, and that they deeply affects human existence (Postman, 1994; 1995).

The cinema, which is one of the most common media tools, is being used increasingly in education. According to Baudrillard, an influential media and 
cinema critic, the signs in modern culture are not having a sense on the grounds and that they are deprived of their referents.

For Baudrillard, as soon as the cinema film comes across people, the frame disappears and they are being invited to a digital life (Baudrillard, 2010b, p. 30). In this virtual reality, where everyday living facts are presented as more "real" than they are, the phenomenon that occurs between individual and movie films can be expressed by "resonance" (Postman, 1994, p. 26), (resonance, as a technical term, means the overlap of frequencies. Accordingly, the two conflicting sources of frequency remain at the frequency of the strong until the weaker one disappears). Whether or not there is physical reality until the collapse of the Tacoma Narrows Bridge has been a matter of debate. The Tacoma Narrows Bridge is caused by wind-induced oscillation, where the frequency of the bridge is equalized with the frequency of the wind, resulting in resonance, causing the bridge to collapse). The individual who is relatively stable in time and space pulls towards the frequency of the presentation in the cinema film, and voluntarily participates in this process which is incompatible with the personality in essence.

\section{Simulation Theory}

The ironic side of Baudrillard's system of thinking is utilizing tales which are not modern at all to criticize the modern world. As it is known, the tales are the ones that have problematic relations with reality; more precisely they are in a reality crisis and only find 'existence' in this crisis. Moreover, although they are a form of sense, they can also be seen as the manifestations for the destruction of reality of unconscious or imagination. At the same time tales attract people by using these destructions. Nonetheless, traditional societies do not live in the world of the tale and myths despite their prevalence -even if we accept that the imaginary/mythic world encompasses them all around- because there is also a reality universe in which the tale/narrative is built likewise/symmetrically. Then what is the link between tales and simulation? The simulation universe shares the same space with the tales for reasons such as being independent of the logic rules and the source of its own reality being itself. Baudrillard explains the simulation as "reproducing/augmenting a reality lacking reality or origin through modellers" (Baudrillard, 2014, p. 13).

Indicators have surrounded us with an unlimited variety; God can only find himself as an indicator. The source of all meanings, even God, as the interchange 
of semantic relations, is a mere indication in simulations (Baudrillard, 2006, p. 20). According to Baudrillard, the simulation universe, which means that a reality is substituted and is more perfect/hyperreal than reality, took its place by covering the world of truth like a membrane (Baudrillard, 2010, p. 23). This cultural universe does not have an authentic root, nor has it been conditioned on any idea or purpose. It does not aim to achieve any principle of goodness or justice, nor of good conception. This universe, which obtains its absolute depth from its absolute shallowness which unlimitedly reflects blinks with illusions, can only be perceived through real-world objects or expressions concerning of them (Deleuze, 2015, p. 23-4). For this reason, Baudrillard often refers to comparative explanations of the simulation universe. Disneyland which is one of the most impressive models of simulation, is the perfect combination of simulacra layers. Disneyland which consists of mix of fear, contradictions and mysteries, gives a collective pleasure similar to religions (Baudrillard, 2014, p. 27). Another example is II. Ramses as a mummy. The mummy after the mummy showed up in the modern world, that is, after entering the modern world by leaving its mysteries at the door, it began to rot (Baudrillard, 2014, p. 23). These two examples show that there is an irreparable discrepancy between the world of reality and the universe of simulation. Baudrillard implies that something that has the appearance of something, in fact, is not the thing, with the breaking of the bond with the metaphysical world that gives authenticity to things. Only the material for the indicator and the production remains. In the desire of visual continuity, simulacra fill our souls from our eyes and transform all the sacred things that are wrapped in secrets into an object of ethnological, anthropological, etc. As a result, the simulation universe has become closed circuit since it has broken its bond with transcendence. For this reason, the simulacrum as an indicator does not have any referent.

\section{Temptingness of Simulation}

Marshall McLuhan, who works on communication tools, has formulated the phrase 'medium is the message', suggesting that the media that transferred the message is also inevitably shaping the content (McLuhan, 2013, p. 23). According to this, mass communication manipulates the messages parallel to its nature. However, in order for the media to be able to transform the message, the individual/society must be tempted, and massification of society is necessary for this process to take place on the social scale. It is not only the mass media 
that constitute the mass; there are many tools that can come to mind, especially commercial products, create many masses from the society. The seduction is possible only on a ground where freedom can be assumed. But how much is it possible to talk about will in the absence of sense? The will is produced synthetically as it is in material things. So the simulation is able to overcome the paradox that it faces (Baudrillard, 1991, p. 57).

\section{Using Ginema as a Simulation Model in Religious Education}

In general, studies on existing or possible relationships between various information tools and religious education are being carried out (Doğan\&Şener, 2014). The fact that it's appealing to large number of people and taking into consideration more than one sense organ, make cinema a current educational issue. However, the machines only produce machines. The texts, images, films, speeches, produced in the computer are the result of mechanical production and carry the characteristics of this production (Baudrillard, 2005c, p. 80). This is also the obstacle that religious films cannot overcome: the indicator loses its imaginariness when it is torn from the bond of transcendence and transformed into a surface, and it is no longer unbearable. Baudrillard expresses the resonance state experienced in the simulacra experience / cinema as 'after the orgy' state. Orgy is the explosion of 'liberties' by destroying all defense mechanisms, all social laws, all the taboos associated with metaphysics. (Baudrillard, 2010a, p. $9)$. With the collapse of the opposite poles, the highest point that the cinema can make audience reach is such an ecstasy. It is pointed out that the viewer is not on the other side of the stage but on the inside of the screen and emotions emerge (Baudrillard, 2010a, p. 9). Identification of role models is another problem. The model is putting itself to forefront by ignoring its objects. The stars are like flashes that flash in the dark for a moment; their lights aren't enduring, they do not brighten the environment and they do not point to any roads.

\section{Conclusion}

Undoubtedly, it is not easy to believe that the world we live in is a simulation and to admit that our existence is a product of simulacra. Because the imagination of the real world outside of a familiar illusion is rather difficult. Baudrillard explanations emphasizes the fact that before using this tool which has suspicious features in the field of religious education that affects human beings ontologically, it is necessary that further investigations should be done. 